\section{Pacific Northwest}

National Laboratory

Operated by Battelle for the

U.S. Department of Energy

\title{
Statewide Savings Projections from the Adoption of a Commercial Building Energy Code in Illinois
}

KA Cort

DB Belzer

September 2002

Prepared for the U.S. Department of Energy

under Contract DE-AC06-76RL01830

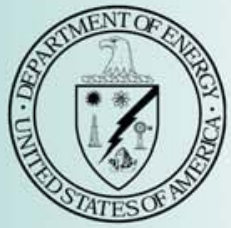




\title{
DISCLAIMER
}

This report was prepared as an account of work sponsored by an agency of the United States Government. Neither the United States Government nor any agency thereof, nor Battelle Memorial Institute, nor any of their employees, makes any warranty, express or implied, or assumes any legal liability or responsibility for the accuracy, completeness, or usefulness of any information, apparatus, product, or process disclosed, or represents that its use would not infringe privately owned rights. Reference herein to any specific commercial product, process, or service by trade name, trademark, manufacturer, or otherwise does not necessarily constitute or imply its endorsement, recommendation, or favoring by the United States Government or any agency thereof, or Battelle Memorial Institute. The views and opinions of authors expressed herein do not necessarily state or reflect those of the United States Government or any agency thereof.

\author{
PACIFIC NORTHWEST NATIONAL LABORATORY \\ operated by \\ BATTELLE \\ for the \\ UNITED STATES DEPARTMENT OF ENERGY
}

under Contract DE-AC06-76RL01830

Printed in the United States of America

Available to DOE and DOE contractors from the

Office of Scientific and Technical Information,

P.O. Box 62, Oak Ridge, TN 37831-0062;

ph: (865) 576-8401

fax: (865) 576-5728

email: reports@adonis.osti.gov

\begin{abstract}
Available to the public from the National Technical Information Service, U.S. Department of Commerce, 5285 Port Royal Rd., Springfield, VA 22161 ph: (800) 553-6847 fax: (703) 605-6900

email: orders@ntis.fedworld.gov

online ordering: http://www.ntis.gov/ordering.htm
\end{abstract}

This document was printed on recycled paper.

$(8 / 00)$ 
PNNL-14015

\title{
Statewide Savings Projections from the Adoption of a Commercial Building Energy Code in Illinois
}

\author{
K.A. Cort \\ D.B. Belzer
}

September 2002

Completed for the Building Standards and Guidelines Program, U.S. Department of Energy.

Completed by Pacific Northwest National Laboratory, Operated for the U.S. Department of Energy by Battelle 


\section{Executive Summary}

ANSI/ASHRAE/IESNA Standard 90.1-1999 Energy Standard for Buildings except LowRise Residential Buildings (hereafter referred to as ASHRAE 90.1-1999 or 90.1-1999) was developed in an effort to set minimum requirements for the energy efficient design and construction of new commercial buildings. A number of jurisdictions in the state of Illinois are considering adopting ASHRAE 90.1-1999 as their commercial building energy code. This report builds on the results of a previous study, Analysis of Potential Benefits and Costs of Adopting ASHRAE Standard 90.1-1999 as a Commercial Building Energy Code in Illinois Jurisdictions, to estimate the total potential impact of adopting ASHRAE 90.1-1999 as a statewide commercial building code in terms of Life-Cycle Cost (LCC) savings, total primary energy savings, and pollution emissions reductions.

Illinois does not currently have a statewide building energy code. Therefore, in the absence of a code, the LCC savings of adopting ASHRAE 90.1-1999 are estimated using two separate baseline scenarios to reflect the variability in current building practices. Similarly, the total primary energy savings are estimated using two sets of baseline assumptions. Finally, the corresponding greenhouse gas emissions reductions $\left(\mathrm{CO}_{2}, \mathrm{SO}_{2}\right.$, $\mathrm{NO}_{\mathrm{x}}, \mathrm{CO}, \mathrm{PM}, \mathrm{VOC}$ ) are estimated using both average and marginal emissions coefficients. The results of this analysis suggest that adopting and enforcing a commercial building energy code throughout the state of Illinois could produce substantial energy and cost savings, while reducing emissions of greenhouse gases. 


\section{Contents}

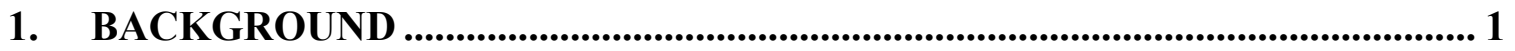

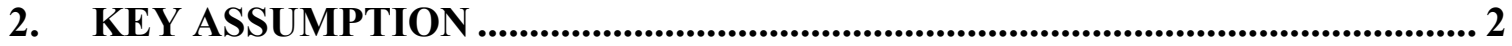

2.1 BUILDING ENVELOPE BASELINE ............................................................. 2

2.2 LIGHTING BASELINE ............................................................................ 2

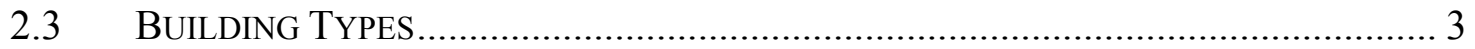

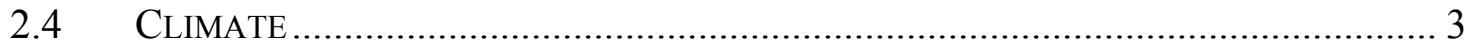

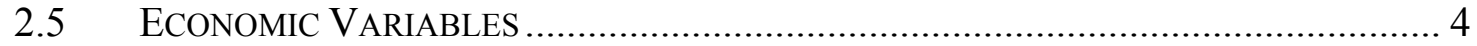

3. ESTIMATED TOTAL STATE IMPACTS ..................................................... 5

3.1 LIFE-CYCLE COST SAVINGS................................................................... 5

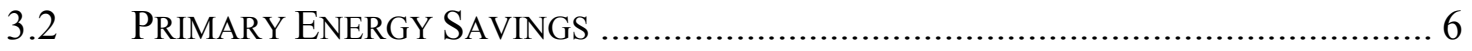

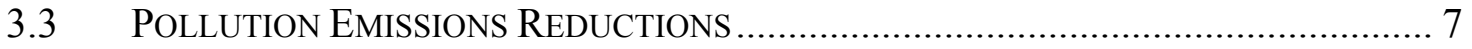

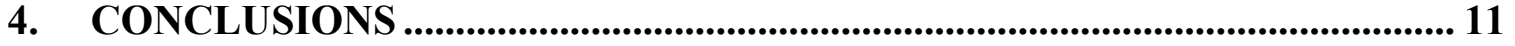

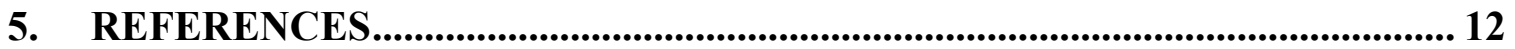

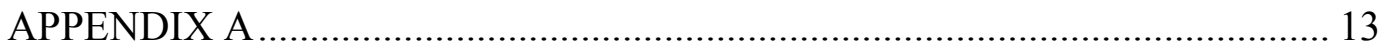

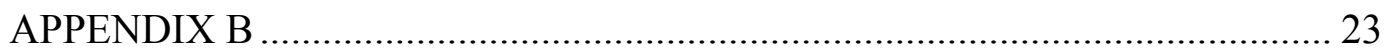

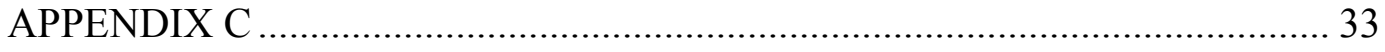

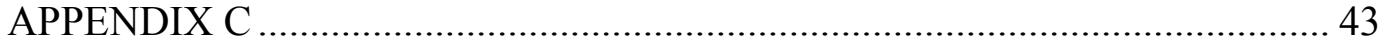




\section{Background}

Illinois does not currently have a statewide building energy code that could be used as a baseline. It is, therefore, not possible to clearly define energy-related baseline characteristics for commercial building construction. While some new buildings may already be meeting or exceeding some of the requirements of ASHRAE 90.1-1999, others may be well below this standard. In an effort to reflect varied practices in the baseline, two separate building envelope baseline scenarios are used to calculate a range of potential savings from energy code adoption.

This study includes the impacts of adopting only the building envelope and lighting requirements of ASHRAE 90.1-1999 and applying it only to new commercial construction. Mechanical requirements are excluded because of expected changes in efficiencies due to federal manufacturing standards as referenced under the Energy Policy and Conservation Act (EPCA) as amended by the 1992 Energy Policy Act (EPAct). Under this legislation, the energy efficiency of most of the heating ventilation, and airconditioning (HVAC) and the service water heating (SWH) equipment regulated under ASHRAE 90.1-1999 is also regulated by federal manufacturing standards, which by law will soon be updated to levels at least as stringent as those in 90.1-1999. Hence, the savings from these equipment requirements will generally occur regardless of the adoption of a building standard in Illinois. Efficiency improvements in equipment that are not covered under EPCA are discussed in Section 5.3 along with other requirements in the HVAC and SWH section of the standard. The potential quantitative impact of the equipment standards has been evaluated in detail in the report, Screening Analysis for EPACT-Covered Commercial HVAC and Water heating Equipment.

This report builds on a previous study that uses prototypical office, retail, and education buildings to estimate Life-Cycle Cost (LCC) savings estimates per square foot. Office, retail, and education buildings made up over $60 \%$ of the total value of new commercial construction in Illinois in 1997 (Census 2000). A 40-year time horizon was chosen for the LCC estimates to capture changes in building energy costs that occur over the life of the building. Specific energy simulation and economic assumptions are discussed more extensively in the report, Analysis of Potential Benefits and Costs of Adopting ASHRAE Standard 90.1-1999 as a Commercial Building Energy Code in Illinois Jurisdictions. The savings results upon which the statewide estimates are based may be found in the appendix of this report. Appendixes A and B include results and assumptions for building prototypes built with ASHRAE 90A-1980 baseline envelope specifications, assuming steel frames and mass walls, respectively. The savings estimates for building prototypes built using 90.1-1989 as the baseline are found in Appendixes C and D for steel frames and mass walls, respectively. 


\section{Key Assumption}

The following section discusses some of the key assumptions necessary to calculate the net present value of benefits and costs to building owners and users in Illinois from the adoption of an energy code.

\subsection{Building Envelope Baseline}

This study uses the requirements of ASHRAE Standard 90A-1980 and ASHRAE 90.11989 to develop separate sets of baseline assumptions for envelope requirements because both standards take different approaches with respect to envelope requirements.

ASHRAE 90A-1980 contains a set of charts, graphs, and equations that must be solved to obtain envelope requirements, while Standard 90.1-1999 contains sets of prescriptive requirements for envelope components along with a performance-based tradeoff approach. Although these requirements are not always directly comparable, in almost all cases the building envelope that is required to meet the 90.1-1999 standard is more energy efficient than the building envelope required to meet 90A-1980.

The ASHRAE 90.1-1989 requirements are described in detail in a previous study. ${ }^{1}$ In most all cases the envelope requirements of ASHRAE 90.1-1989 are significantly more stringent than those of 90A-1980. In many cases, the envelope requirements of 90.1-1989 are more stringent than those required by 90.1-1999. Although the envelope design criteria for either ASHRAE 90A-1980 or 90.1-1989 may not accurately reflect specific current building practices in Illinois, together they represent a wide range of building envelope characteristics. It is likely that most new buildings are built at least to the standards specified in 90A-1980 and, at most, to a level of 90.1-1989.

\subsection{Lighting Baseline}

Designers and builders in the state of Illinois are not required to adopt lighting practices that meet or exceed any mandated level. However, due to overall improvements in lighting technologies, it is likely that builders are installing lighting systems that would exceed the 90A-1980 requirements for building types included in the evaluation. In order to reflect this practice, this study uses the lighting requirements of 90.1-1989 to represent the baseline lighting levels for both baseline scenarios. It is worth noting, however, that despite technological improvements, it is possible for someone to build a commercial building below the level specified by the 90.1-1989 requirements. This would most likely be a result of excessive use of less efficient lighting technologies such as incandescent and older fluorescent (T12) or from illumination levels that exceed the common practice represented by the 90.1-1989 lighting power limits.

\footnotetext{
${ }^{1}$ Analysis of Potential Benefits and Costs of Adopting ASHRAE Standard 90.1-1999 as a Commercial Building Energy Code in Illinois Jurisdictions
} 


\subsection{Building Types}

Approximately 60 million square feet of new commercial building space is constructed in Illinois each year ${ }^{2}$. It is estimated that office, retail, and education buildings make up more than $60 \%$ of the total square feet of new commercial space. As a result, this study focuses on the LCC and energy savings estimates for these building types and estimates average savings for the remaining building types. Buildings are weighted appropriately, as described in Table 1. In addition to the categories listed in Table 1, buildings were weighted by type of wall construction (e.g., steel frame with siding versus mass wall construction) and office buildings were further categorized by window-to-wall ratios, based on information from the 1992 Commercial Buildings Energy Consumption Survey (CBECS).

Table 1. Building Weights

\begin{tabular}{|c|c|}
\hline BUIDING TYPE & \begin{tabular}{|l} 
ESTIMATED \\
SQUARE \\
FOOTAGE \\
(In Millions) \\
\end{tabular} \\
\hline Office & 15.9 \\
\hline - "Small” Office (1-2 floors) & 9.1 \\
\hline - "Large" Office (3 or more floors) & 6.8 \\
\hline Retail & 15.9 \\
\hline Education & 7.0 \\
\hline - Single-story (Elementary) & 2.8 \\
\hline - $\quad$ More than one floor & 4.2 \\
\hline Other & 21.4 \\
\hline TOTAL & 60.2 \\
\hline
\end{tabular}

It is assumed that these representative buildings are heated with a gas furnace and cooled with an electric air conditioner. It is assumed that all buildings are well operated (e.g., heating is set back when buildings are not occupied). When a building is operated in this manner, the energy losses that would occur from heat losses through relatively poorly insulated roofs, walls, and windows would be minimized. By assuming buildings are well-operated and heated with gas, the prototype buildings chosen in the study most likely represent the lower end of potential energy savings from envelope improvements.

\subsection{Climate}

The climate zone is defined by long-term weather conditions, which affect heating and cooling loads in buildings. The zones are based on an annual average number of degreedays, which are a measurement of how cold/hot a building location is relative to the base

\footnotetext{
2 This estimate is based on 1997 Census study (Census 2000), which estimates total expenditures on new commercial construction by building type in Illinois. New commercial square footage estimates are derived by dividing the total dollars spent on new commercial construction by the average cost/s.f. (MEANS) by building category. These numbers are then adjusted to fit total U.S. square footage estimates listed in the Statistical Abstract of the United States (2000).
} 
temperature ${ }^{3}$. Although Illinois has varying temperatures throughout the state, this analysis focuses on the northern region where much of the population growth and building construction is occurring. The climate in northern Illinois is generally defined as having fewer than 3000 average annual cooling degree-days (CDD) and 5500 to 7000 average annual heating degree-days (HDD) . Representative weather data is taken from the Typical Meteorological Year (TMY) weather data set.

\subsection{Economic Variables}

The economic benefits and costs of adopting 90.1-1999 are determined utilizing the LCC approach, which compares the monetary savings over a specified time horizon in comparison to the associated costs of complying with the code. For this study the LCC is a general measure of the cost of operating a building over its assumed 40 -year lifetime and includes the initial incremental construction cost, replacement of key components, and annual energy expenditures. A key assumption in the valuation of future benefits and costs is the time-value of money or discount rate that reflects the opportunity cost of capital. This study uses a constant 7\% (real) discount rate, which is consistent with the value used by U.S. Department of Energy in analyses of residential and commercial equipment efficiency standards.

Several factors influence the cost and savings from adopting an energy efficiency building code -first costs, replacement costs, maintenance costs, and energy savings. The primary costs associated with code adoption are the incremental costs of required materials and installation that will contribute to reduced annual energy consumption (e.g., higher levels of insulation, more efficient light fixtures) relative to the cost of building materials that would satisfy a less stringent set of requirements. These costs are often referred to as "first costs," as they are incurred when the building is first built. The collection and treatment of first costs for lighting and building envelope materials are discussed in the previous Pacific Northwest National Laboratory (PNNL) study ${ }^{4}$.

The primary ongoing monetary benefit of an energy code is the energy that is saved over the life of a building by using relatively more energy-efficient designs, materials and equipment. The incremental energy savings are valued using forecasted average commercial gas and electricity rates over a specified time horizon. The resulting LCC savings and primary energy savings for all of Illinois are estimated in the following sections.

\footnotetext{
${ }^{3}$ The daily heating degree days (HDD) is the numerical difference between a day's average temperature and $65^{\circ} \mathrm{F}$ (HDD is zero if the day's average temperature is less than $65^{\circ} \mathrm{F}$ and the annual HDD is the sum of the daily HDD for the year. The daily cooling degree days (CDD) is the numerical difference between a day's average temperature and $50^{\circ} \mathrm{F}$ (CDD is zero if the day's average temperature greater than $50^{\circ} \mathrm{F}$ ) and annual CDD is the sum of the daily CDD for the year.

${ }^{4}$ Analysis of Potential Benefits and Costs of Adopting ASHRAE Standard 90.1-1999 as a Commercial Building Energy Code in Illinois Jurisdictions
} 


\section{Estimated Total State Impacts}

All LCC savings and energy savings described in this section stem from a previous study that analyzed energy use and LCC savings for selected prototypical buildings simulated with Illinois climate characteristics, the results of which are included in the appendix. Quantitative measures of energy-use impacts were estimated using the Building Loads Analysis and System Thermodynamics (BLAST) simulations and combined with the energy and capital costs to derive LCC savings per square foot.

\subsection{Life-Cycle Cost Savings}

The LCC savings per square foot for each prototypical building included in the study are listed in Table 2. The total annual LCC savings for Illinois are estimated using the overall commercial floor space weights listed in Table 1, along with wall construction and window-to-wall ratio splits from CBECS (1992), and are shown in the bottom row of Table 2. These estimates assume the energy and cost savings estimated for the building prototypes modeled are representative of new building construction in Illinois.

Table 2. LCC Savings by Building Type and State Totals from 90.1-1999 adoption

\begin{tabular}{|c|c|c|c|c|}
\hline \multirow[t]{2}{*}{ BUIDING TYPE } & \multicolumn{2}{|c|}{ 90A-1980 Baseline } & \multicolumn{2}{|c|}{ 90.1-1989 Baseline } \\
\hline & Steel frame & Mass wall & Steel frame & Mass wall \\
\hline & $\begin{array}{l}\text { LCC } \\
\text { Savings } \\
\text { (\$/ S.F.) }\end{array}$ & $\begin{array}{c}\text { LCC } \\
\text { Savings } \\
\text { (\$/ S.F.) }\end{array}$ & $\begin{array}{c}\text { LCC } \\
\text { Savings } \\
\text { (\$/ S.F.) }\end{array}$ & $\begin{array}{l}\text { LCC } \\
\text { Savings } \\
\text { (\$/ S.F.) }\end{array}$ \\
\hline \multicolumn{5}{|l|}{ Office } \\
\hline \multicolumn{5}{|l|}{ "Small" Office (1-2 floors) } \\
\hline $\begin{array}{l}\text { - With less than } 38 \% \text { window-to- } \\
\text { wall ratio }\end{array}$ & .97 & .99 & 1.33 & 1.37 \\
\hline $\begin{array}{l}\text { - With more than } 38 \% \text { window-to- } \\
\text { wall ratio }\end{array}$ & .94 & .98 & 1.71 & 1.79 \\
\hline \multicolumn{5}{|l|}{ "Large" Office (3 or more floors) } \\
\hline $\begin{array}{l}\text { - With less than } 38 \% \text { window-to- } \\
\text { wall ratio }\end{array}$ & .90 & .89 & .99 & 1.04 \\
\hline $\begin{array}{l}\text { - With more than } 38 \% \text { window-to- } \\
\text { wall ratio }\end{array}$ & .84 & .85 & 1.23 & 1.31 \\
\hline Retail & 1.50 & 1.55 & 1.97 & 2.00 \\
\hline \multicolumn{5}{|l|}{ Education } \\
\hline - $\quad$ Single-story (Elementary) & .54 & .44 & .63 & .65 \\
\hline - $\quad$ More than one floor & .69 & .50 & .57 & .60 \\
\hline Other (Average) & .91 & .89 & 1.20 & 1.25 \\
\hline $\begin{array}{l}\text { Total Annual LCC Savings in Illinois } \\
\text { (Derived from per square foot savings) }\end{array}$ & \multicolumn{2}{|c|}{ \$61 Million } & \multicolumn{2}{|c|}{ \$83 Million } \\
\hline
\end{tabular}


Because the first cost differences are more significant for building designs that are moving from a 90A-1980 baseline to 90.1-1999, the total LCC savings is less than the LCC savings using the 90.1-1989 baseline. Both scenarios, however, produce annual LCC savings in excess of $\$ 60$ million to the state of Illinois.

The annual LCC savings is equivalent to the net present value of the changes in capital (first) and energy costs associated with code adoption for all new buildings built in a given year. Assuming approximately 60 million square feet of building space is added to the commercial building stock each year, the net present value for construction over a 20year period would range from around $\$ 700,000$ to nearly 1 billion dollars (See Figure 1). The net present value is calculated by discounting the LCC savings for each future year's construction (e.g., $\$ 61$ million or $\$ 83$ million, depending on the chosen baseline) back to 2002 , using a discount rate of $7 \%{ }^{5}$.

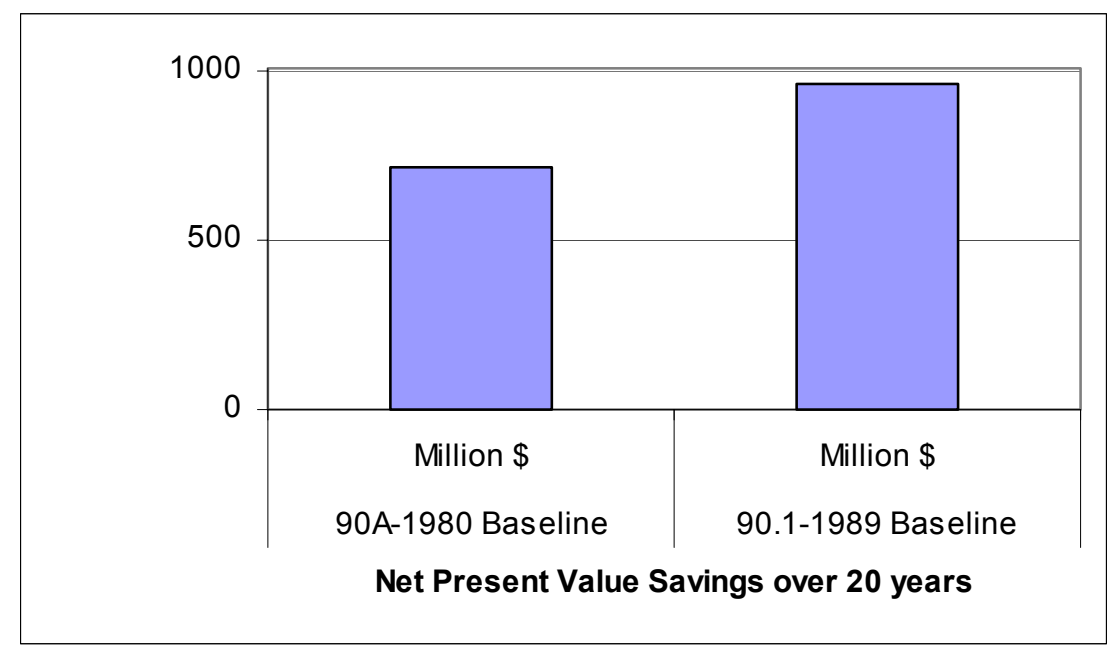

Figure 1. Net Present Value from 90.1-1999 Code Adoption over a 20-Year Period

\subsection{Primary Energy Savings}

Primary energy savings are reported in trillion Btu (TBtu) per year. These results are derived from the site electricity savings ${ }^{6}$ per square foot (from fan systems, cooling, and lighting savings), added together with the natural gas savings (or losses) for each building type, multiplied by the total number of square feet in each building category. The differences in envelope requirements between the baseline ASHRAE 90A-1980 and 90.1-1999 are more significant than the differences in envelope requirements between 90.1-1989 and 90.1-1999. As a result, the annual energy savings using the 90A-1980 baseline are greater than the savings using the 90.1-1989 baseline, as illustrated in Table 3.

\footnotetext{
${ }^{5}$ Assuming a constant rate of annual LCC savings.

${ }^{6}$ Site electricity is converted to primary electricity to derive primary energy.
} 
Table 3. Primary Energy Savings from 90.1-1999 adoption (in TBtu/Year) *

\begin{tabular}{|l|c|c|c|c|c||}
\hline BASELINE & 2002 & 2005 & 2010 & 2015 & 2020 \\
\hline $\mathbf{9 0 A - 1 9 8 0}$ & $\mathbf{1 . 2}$ & $\mathbf{4 . 7}$ & $\mathbf{1 0 . 6}$ & $\mathbf{1 6 . 4}$ & $\mathbf{2 2 . 3}$ \\
\hline $\mathbf{9 0 . 1 - 1 9 8 9}$ & $\mathbf{0 . 9}$ & $\mathbf{3 . 8}$ & $\mathbf{8 . 5}$ & $\mathbf{1 3 . 3}$ & $\mathbf{1 8 . 0}$ \\
\hline
\end{tabular}

*Using Average Electricity Conversion Factors

The energy savings resulting from energy code adoption persist for the life of the building. Although the total amount saved in the first year of adoption may be relatively modest compared with the total amount of energy consumed by the entire commercial sector, these savings from new buildings adopting codes in any given year continue into the future as more new buildings are added to the existing building stock. The savings from code adoption relative to total energy consumption become more significant in future years. Figure 2 illustrates the potential impact through 2020 of code adoption (applied only to new construction) on total commercial energy consumption in Illinois. This does not include potential savings if the code is applied to commercial building renovations ${ }^{7}$.

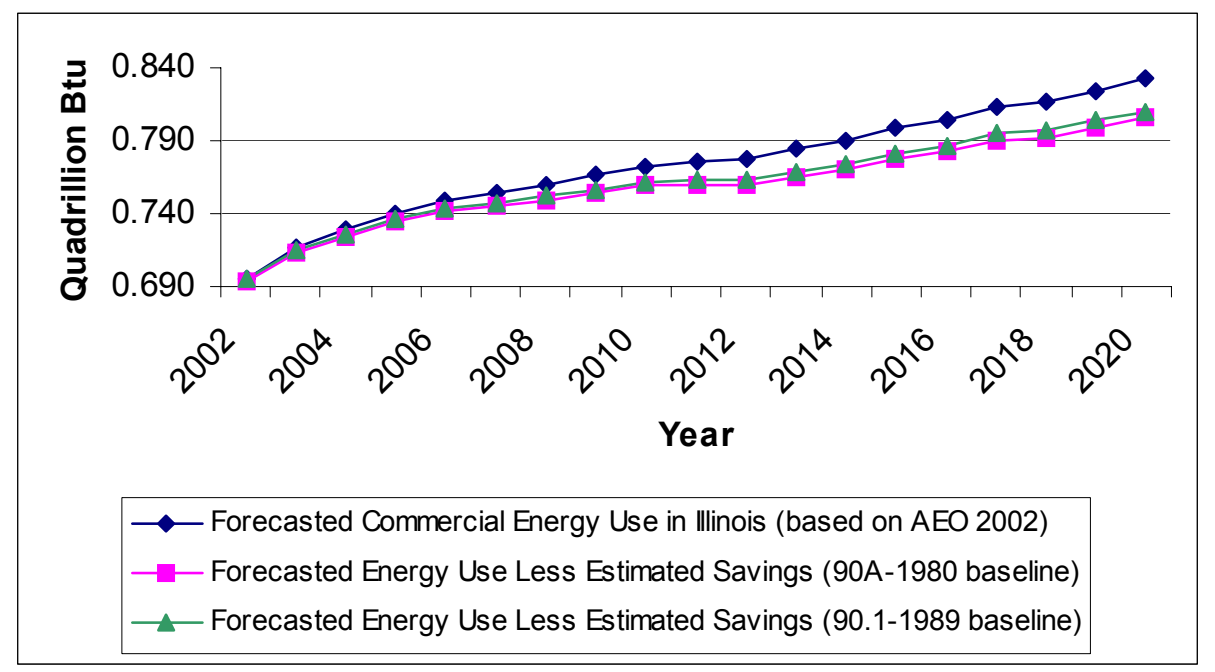

Figure 2. Forecasted Commercial Energy Use in Illinois With and Without Adoption of 90.1-

1999

\subsection{Pollution Emissions Reductions}

Emissions reductions are based on the energy savings calculations described in Section 3.2. Emissions coefficients for all primary greenhouse gases $\left(\mathrm{CO}_{2}, \mathrm{SO}_{2}, \mathrm{NO}_{\mathrm{x}}\right.$, VOC, CO, and PM) are based on U.S. Department of Energy estimates. ${ }^{8}$ The coefficients are based on the content of the greenhouse gas in each fuel type. For example, the carbon emission factors are based on the carbon content of the fuel and the fraction of the fuel

\footnotetext{
${ }^{7}$ The value of annual investment in commercial alternations and renovations is approximately $50 \%$ of the value of new construction in a given year. Expanding the application of the code to commercial building alternations and renovations would potentially significantly increase the statewide energy savings.

${ }^{8}$ The GPRA 2002 Data Call, produced by DOE (which are the same as the AEO 2000 emission coefficient assumptions used by EIA)
} 
consumed in combustion. Emissions factors can be in terms of marginal emissions rates, which focus on future displaced energy consumption, or the emissions factors can be average rates, which take an average of the fuel mixes being used today. The marginal and average rates yield significantly different emission displacement numbers.

The marginal rates are based on the forecasted displaced fuel mix for the next 20 years 9 . The average coefficients for electricity are based on the electricity generation mix in Illinois, which is approximately $45 \%$ from coal generating plants, $50 \%$ from nuclear plants, and 4\% from natural gas plants (EIA 2000b). Note that there are no greenhouse gas emissions associated with the production of nuclear power.

The emissions coefficients are multiplied by the primary energy savings, as listed in Section 3.2, to yield the total emissions reductions listed in Tables 3, 4, and 5.

Table 3. Carbon Equivalent Emissions Reductions from 90.1-1999 adoption (in Metric Tons/Year)

\begin{tabular}{||l|c|c|c|c|c||}
\hline BASELINE & $\mathbf{2 0 0 2}$ & $\mathbf{2 0 0 5}$ & $\mathbf{2 0 1 0}$ & $\mathbf{2 0 1 5}$ & \multicolumn{1}{l|}{$\mathbf{2 0 2 0}$} \\
\hline 90A-1980 (Average*) & 14,315 & 57,259 & 128,833 & 200,407 & 271,981 \\
\hline 90.1-1989 (Average*) $^{*}$ & 11,370 & 45,479 & 102,327 & 159,175 & 216,023 \\
\hline 90A-1980 (Marginal**) & 21,752 & 89,860 & 187,610 & 258,624 & 326,818 \\
\hline 90.1-1989 (Marginal**) & 17,978 & 74,445 & 154,552 & 210,902 & 264,747 \\
\hline
\end{tabular}

*Using Average Carbon Emissions Coefficients

**Using Marginal Carbon Emissions Coefficients

As illustrated in the Table 3 and Figure 3, the displaced emissions estimates vary significantly depending on which rate (marginal or average) is used. The average coefficients provide a snap shot of the present situation, representing current fuel mixes in Illinois. In the case of Illinois, this includes a relatively high percentage of nuclear power generation, which produces no greenhouse emissions. The marginal rates may be more appropriate to observe if the focus is on future displaced generation (focusing on the sources of potential marginal power generation). Because of the difficulty of locating nuclear and hydro plants, these zero emitting power sources are not considered in the development of the marginal emissions coefficients.

\footnotetext{
${ }^{9}$ In the absence of state-specific data, it was assumed that the Illinois marginal fuel mix would be same as the national estimates of displaced fuel.
} 


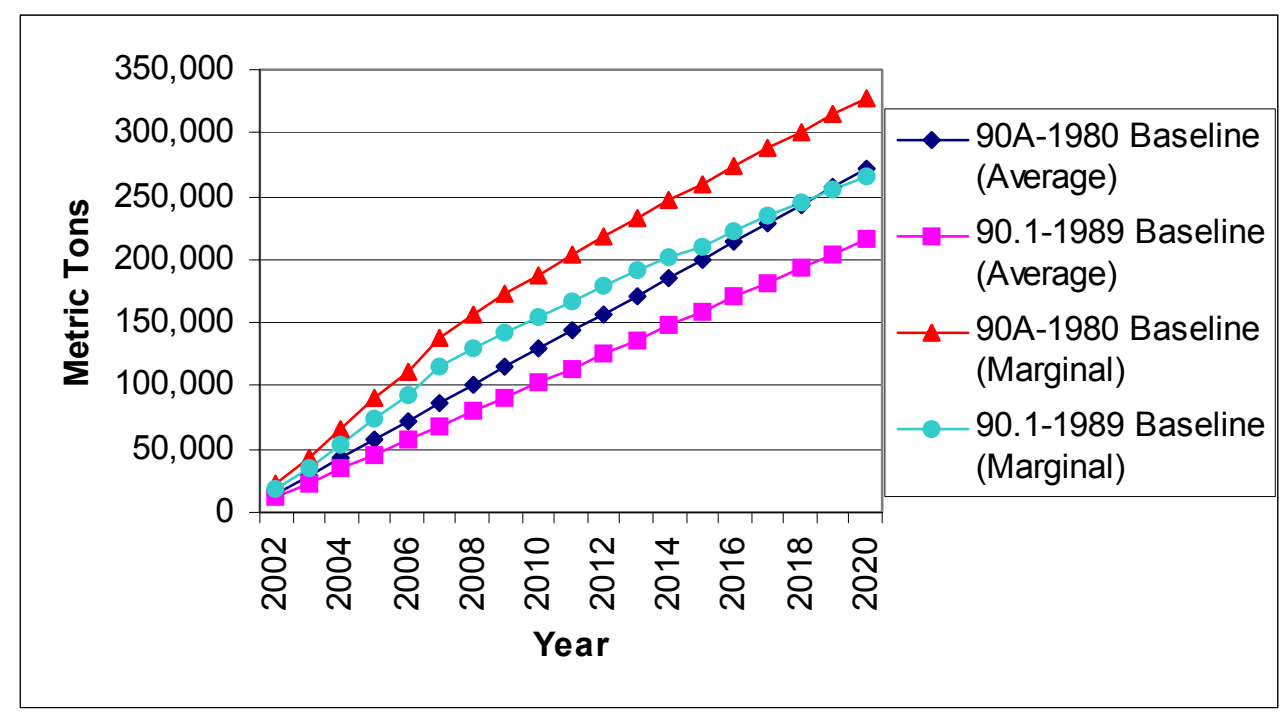

Figure 3. Carbon Emissions Reduction from 90.1-1999 adoption using Marginal and Average Emissions Coefficients

In either case (using marginal or average coefficients), the potential carbon emissions reductions stemming from building code energy savings are significant, ranging from 10,000-20,000 metric tons in the short term, increasing up to 330,000 metric tons in the longer term (2020).

Table 4. Other Greenhouse Gas Emissions from 90.1-1999 adoption Calculated Using Average Emission Coefficients

\begin{tabular}{|c|c|c|c|c|}
\hline \multirow{2}{*}{$\begin{array}{r}\text { OTHER GREENHOUSE GASES } \\
\text { year }\end{array}$} & \multicolumn{2}{|c|}{$\begin{array}{c}\text { EMISSIONS REDUCTION } \\
\text { (Metric Tons) } \\
\text { 90A-1980 Baseline } \\
\end{array}$} & \multicolumn{2}{|c|}{$\begin{array}{c}\text { EMISSIONS REDUCTION } \\
\text { (Metric Tons) } \\
\text { 90.1-1989 Baseline } \\
\end{array}$} \\
\hline & 2002 & 2020 & 2002 & 2020 \\
\hline Sulfur Dioxide $\left(\mathrm{SO}_{2}\right)$ & 317 & 6032 & 282 & 5359 \\
\hline Nitrous Oxides $\left(\mathrm{NO}_{\mathbf{x}}\right)$ & 141 & 2679 & 115 & 2191 \\
\hline Carbon Monoxide (MO) & 6 & 118 & 3 & 53 \\
\hline Particulate Matter $\left(\mathbf{P M}_{10}\right)$ & 7 & 128 & 6 & 114 \\
\hline Volatile Organic Compound (VOC) & 1 & 12 & 0 & 6 \\
\hline
\end{tabular}

Tables 4 and 5 provide the potential emissions reductions for all other major green house gases. For the most part, the results from using marginal and average emissions coefficients follow the same pattern as the carbon equivalent emissions shown in Table 3. That is, the emissions reduction under the marginal rates produce greater emissions reductions due to the fact that nuclear power (a zero emitting source) would not be included in the future mixes of the power generation. The exception, however, is that sulfur dioxide emissions and particulate matter are greater when calculated with average coefficient because of the high percentage of coal power plants (which produces a high amount of $\mathrm{SO}_{2}$ and $\mathrm{PM}$ ) in the current mix of Illinois power generation. 
Table 5. Other Greenhouse Gas Emissions from 90.1-1999 adoption Calculated Using Marginal Emission Coefficients

\begin{tabular}{|c|c|c|c|c|}
\hline \multirow{2}{*}{$\begin{array}{r}\text { OTHER GREENHOUSE GASES } \\
\text { year }\end{array}$} & \multicolumn{2}{|c|}{$\begin{array}{c}\text { EMISSIONS REDUCTION } \\
\text { (Metric Tons) } \\
\text { 90A-1980 Baseline }\end{array}$} & \multicolumn{2}{|c|}{$\begin{array}{c}\text { EMISSIONS REDUCTION } \\
\text { (Metric Tons) } \\
\text { 90.1-1989 Baseline }\end{array}$} \\
\hline & 2002 & 2020 & 2002 & 2020 \\
\hline Sulfur Dioxide $\left(\mathrm{SO}_{2}\right)$ & 246 & 4575 & 219 & 4065 \\
\hline Nitrous Oxides $\left(\mathrm{NO}_{\mathrm{x}}\right)$ & 179 & 2913 & 149 & 2399 \\
\hline Carbon Monoxide (MO) & 28 & 345 & 22 & 255 \\
\hline Particulate Matter (PM$\left.{ }_{10}\right)$ & 5 & 106 & 5 & 94 \\
\hline Volatile Organic Compound (VOC) & 3 & 35 & 3 & 26 \\
\hline
\end{tabular}




\section{Conclusions}

Assuming that the new building code impacts approximately 60 million square feet of new commercial building space each year and that the building prototypes modeled in this study are representative of new building stock in Illinois, the monetary impact of adopting a state-wide building energy code in Illinois could produce approximately $\$ 60$ $\$ 80$ million dollars of LCC savings for each year of construction. When evaluating the benefits of the code over a series of future years, the net present value represents an aggregate measure of the discounted total dollar savings to the state. Including future construction over the next 20 years, the estimated net present value is on the order of $\$ 1$ billion. In addition, the energy savings from code adoption could significantly reduce the need to expand power generation and would produce significant environmental benefits. Carbon dioxide emissions could potentially be reduced by over 300,000 metric tons in the next 20 years. 


\section{References}

American Society of Heating, Refrigerating and Air-Conditioning Engineers (ASHRAE) and Illuminating Engineering Society of North America (IESNA) 1999. ASHRAE Standard Energy Standard for Buildings Except Low-Rise Residential Buildings. 1999.

Belzer, DB with KA Cort, M Friedrich, EE Richman, and DW Winiarski. 2002. Analysis of Potential Benefits and Costs of Adopting ASHRAE Standard 90.1-1999 as a Commercial Building Energy Code in Illinois Jurisdictions. Pacific Northwest National Laboratory. April 2002.

Energy Information Administration (EIA) 2001a. Annual Energy Outlook 2002 with Projections to 2020. U.S. Department of Energy. December 2001. Washington D.C.

Energy Information Administration (EIA). 1992. Commercial Building Energy Consumption and Expenditures Survey 1992 (CBECS 92), Public Use Data, Micro-data files on EIA website: ftp://ftp.eia.doe.gov/pub/consumption/commercial/micro.data/ U.S. Department of Energy. Washington D.C.

Energy Information Administration (EIA). 2001b. "State Energy Profiles," U.S. Department of Energy. August 2001. Washington D.C.

R.S. MEANS Company. "MEANS Cost Works 2001.” Kingston, MA. 2001.

Somasundaram, S. PR Armstrong, DB Belzer, SC Gaines, DL Hadley, S Katipumula, DL Smith, and DW Winiarski. 2000. Screening Analysis for EPACT-Covered Commercial HVAC and Water-Heating Equipment. Pacific Northwest National Laboratory, PNNL13232. April 2000.

U.S. Census Bureau (Census). 2000. "1997 Economic Census Construction Geographic Area Series.” U.S. Department of Commerce, March 2000. Washington D.C.

U.S. Department of Commerce. 2000. Statistical Abstract of the United States 2000. September 2000. Washington D.C. 
APPENDIX A

Metal Frame Results

90.1-1980 Envelope Baseline 


\begin{tabular}{|c|c|c|c|c|c|c|}
\hline \multicolumn{3}{|c|}{ Small Office (WWR=0.18) } & & & & \\
\hline Wall Type: & Steel Fran & & & & & \\
\hline Bldg. Size & $10,000 \mathrm{sq}$. & & & Standard & evel & \\
\hline & & & $\begin{array}{c}90 A-1980 \\
\text { Base }\end{array}$ & $\begin{array}{c}\text { 90.1-1999 } \\
\text { Envelope } \\
\text { Only }\end{array}$ & $\begin{array}{c}\text { 90.1-1999 } \\
\text { Lighting Only }\end{array}$ & $\begin{array}{c}\text { 90.1-1999 } \\
\text { Envelope \& } \\
\text { Lighting }\end{array}$ \\
\hline Envelope & Area (sq. $f$ & & & & & \\
\hline Windows & 1,014 & U-factor(std) & 0.720 & 0.570 & & 0.570 \\
\hline 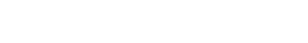 & & sh. coef.(std) & 0.840 & 0.453 & & 0.453 \\
\hline (Window-Wall Rat & io $=0.18)$ & U-factor(cost) & 0.72 & 0.571 & & 0.571 \\
\hline & & sh. coef.(cost) & 0.836 & 0.453 & & 0.453 \\
\hline 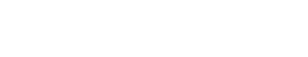 & & $\operatorname{cost}(\$ /$ sqft $)$ & $\$ 4.66$ & $\$ 7.38$ & & $\$ 7.38$ \\
\hline Opaque Walls & 4,619 & U-factor & 0.132 & 0.084 & & 0.084 \\
\hline 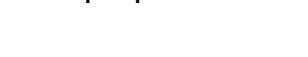 & & $\operatorname{cost}(\$ /$ sqft $)$ & $\$ 0.33$ & $\$ 0.70$ & & $\$ 0.70$ \\
\hline Roof & 10,000 & U-factor & 0.074 & 0.063 & & 0.063 \\
\hline 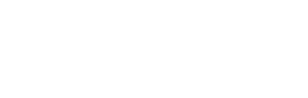 & (feet) & $\operatorname{cost}(\$ /$ sqft $)$ & $\$ 1.02$ & $\$ 1.13$ & & $\$ 1.13$ \\
\hline Slab perimeter & 433 & U-factor & 0.125 & not req'd & & not req'd \\
\hline 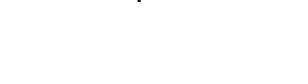 & & $\begin{array}{r}\operatorname{cost}(\$ / \mathrm{ft})^{*} \\
{ }^{*} 24-\text { inch depth }\end{array}$ & $\$ 2.08$ & $\$ 2.08$ & & $\$ 2.08$ \\
\hline Envelope Cos & $\mathrm{t}$ (incremen & & $\$ 17,331$ & $\$ 22,029$ & & $\$ 22,029$ \\
\hline Lighting & & & & & & \\
\hline Lighting Power & ensity & watts/sqft & 1.63 & & 1.30 & 1.30 \\
\hline Lighting Cost & & $\$ /$ sqft & $\$ 1.57$ & & $\$ 1.76$ & $\$ 1.76$ \\
\hline Total Lighting & Cost & & $\$ 15,720$ & & $\$ 17,554$ & $\$ 17,554$ \\
\hline Construction Cost & & & $\$ 33,050$ & $\$ 37,749$ & $\$ 34,885$ & $\$ 39,584$ \\
\hline Annual Energy Col & nsumption & & & & & \\
\hline Electricity, lights & and plugs & MMBtu & 321 & 321 & 281 & 281 \\
\hline Electricity, HVAC & & MMBtu & 119 & 100 & 107 & 88 \\
\hline Natural Gas & & MMBtu & 108 & 88 & 124 & 103 \\
\hline Total Annual Eners & gy Cost & & $\$ 9,234$ & $\$ 8,732$ & $\$ 8,335$ & $\$ 7,820$ \\
\hline Economic Measure & & & & & & \\
\hline Life-Cycle Cost & Savings & & & $\$ 1,163$ & $\$ 8,372$ & $\$ 9,715$ \\
\hline Savings-to-Inves & tment Ratic & $(\mathrm{SIR})$ & & 1.2 & 4.2 & 2.2 \\
\hline Adjusted IRR & & & & $7.5 \%$ & $10.9 \%$ & $9.2 \%$ \\
\hline
\end{tabular}

Notes:

1 No economizer used

22001 electricity price $=6.6 \mathrm{cents} / \mathrm{kWh} \quad 2001$ gas price $=\$ 6.71 / \mathrm{MMBtu}$

3 Years for Analysis $=40 \quad$ Discount Rate $=\mathbf{7 . 0 \%}$

Life-cycle cost savings includes replacement costs and residual values 


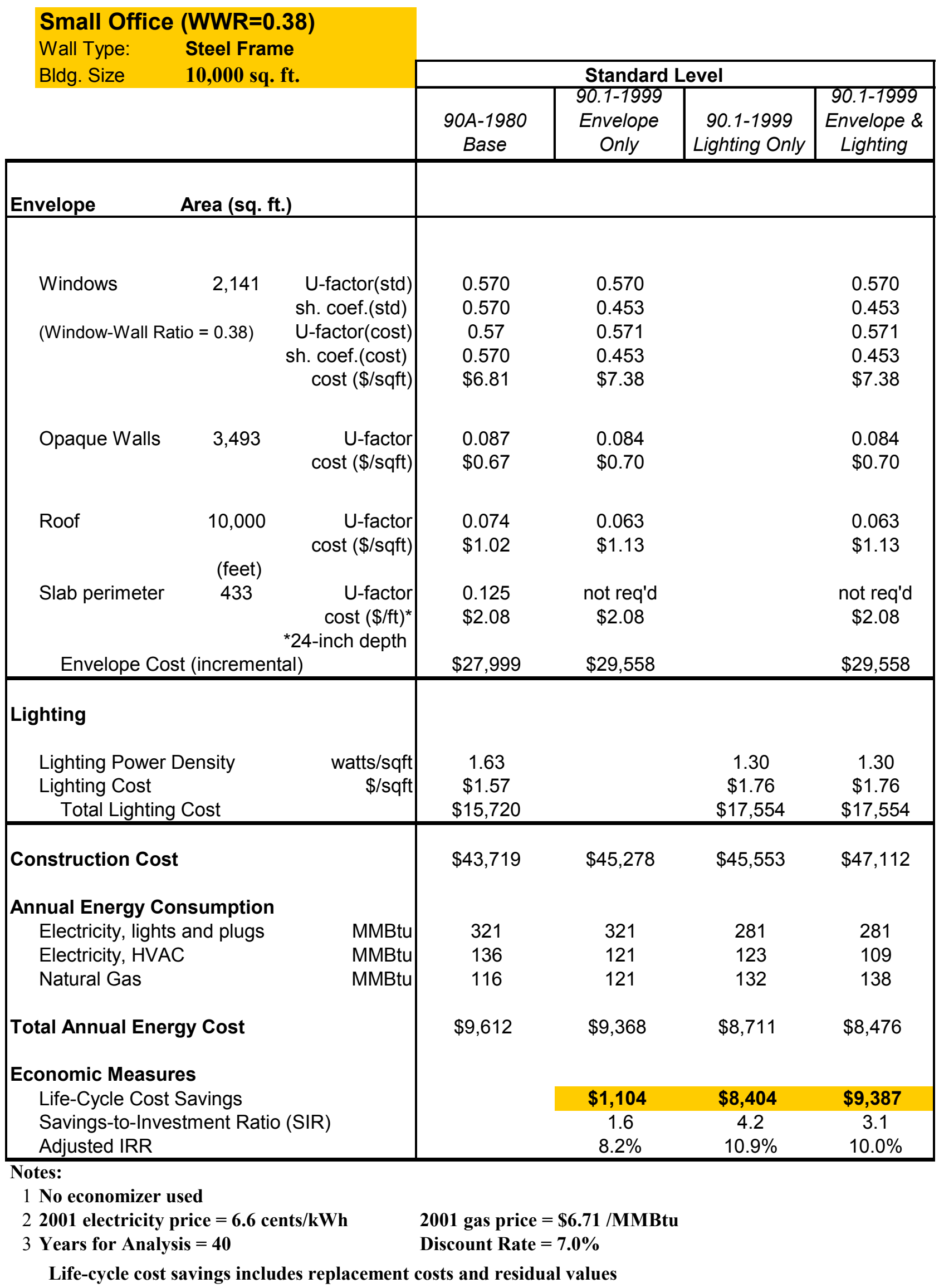




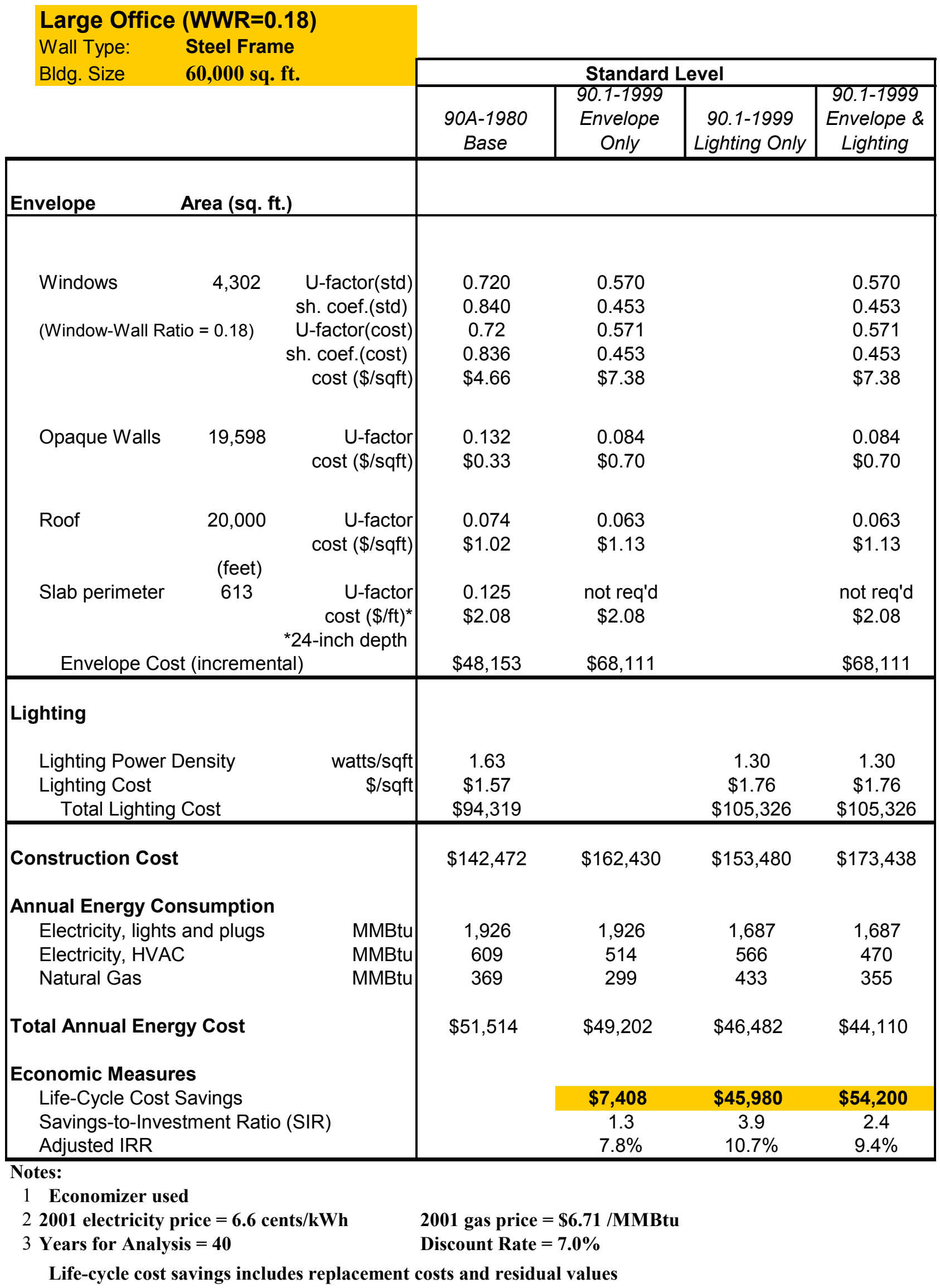




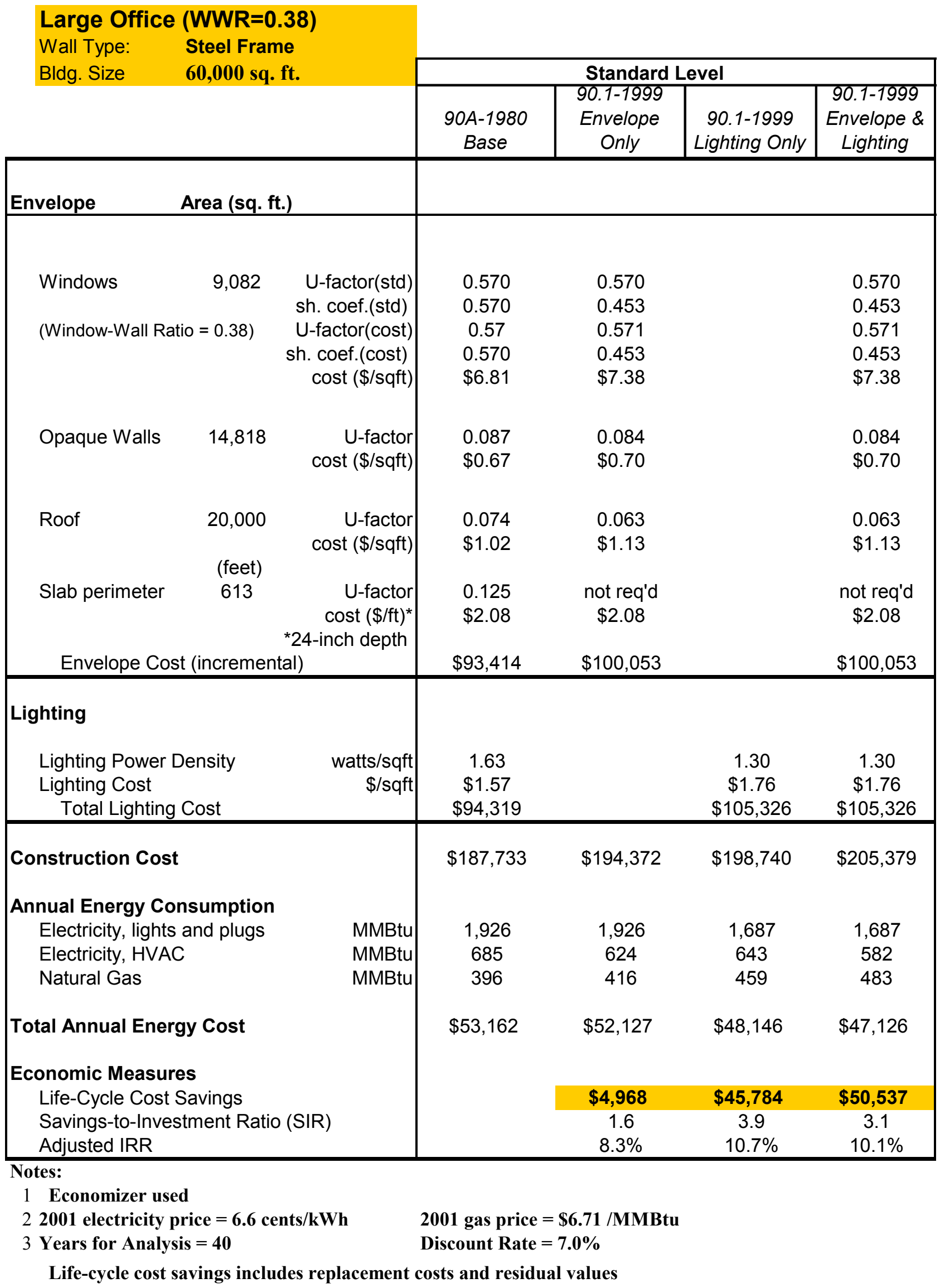




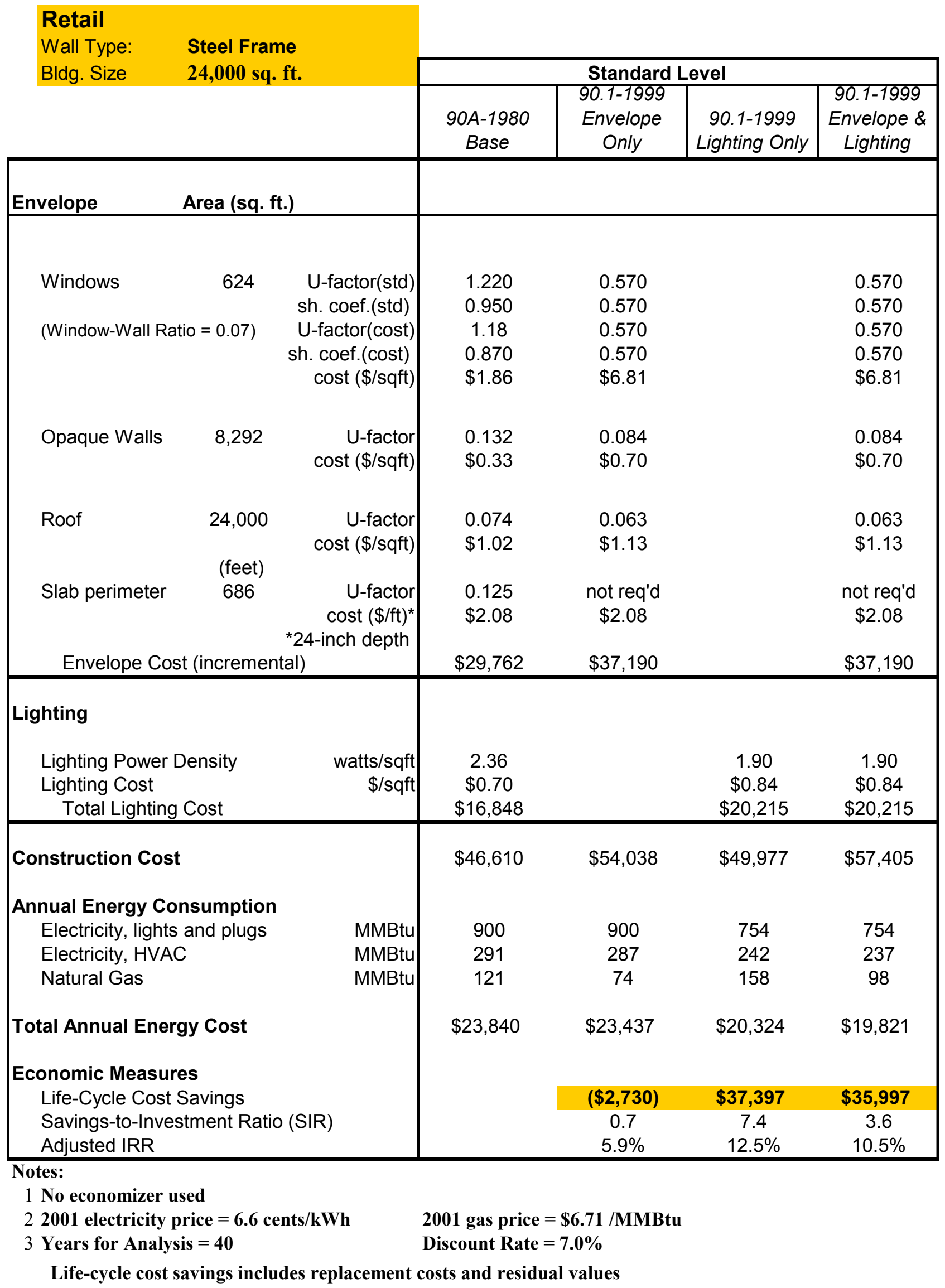




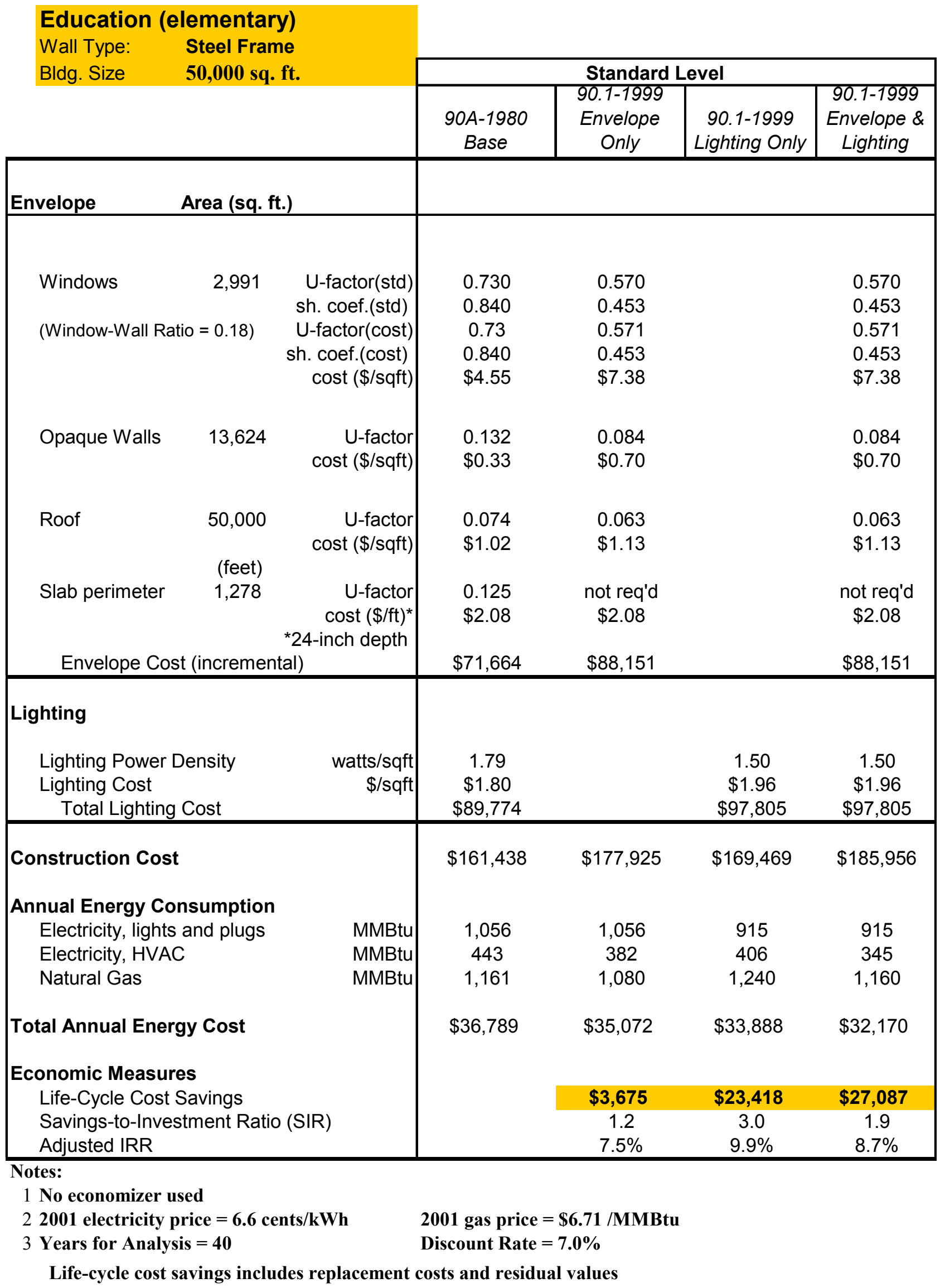




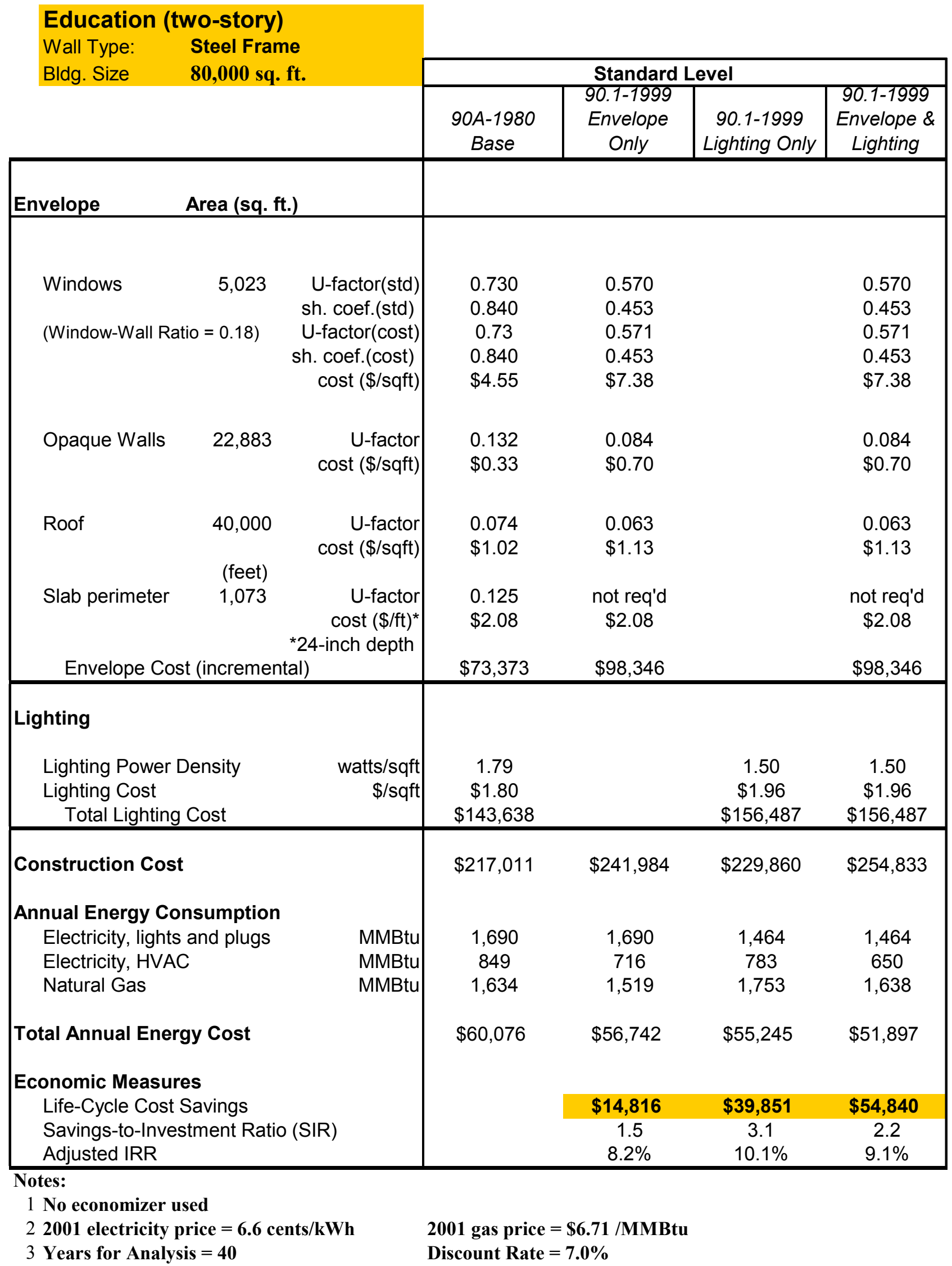

Life-cycle cost savings includes replacement costs and residual values 


\begin{tabular}{|c|c|c|c|c|c|c|}
\hline \multicolumn{7}{|c|}{ Summary of Results by Building } \\
\hline \multirow[t]{2}{*}{ Wall Type: } & \multicolumn{2}{|c|}{ Steel Frame } & \multicolumn{4}{|c|}{ Standard Level } \\
\hline & & & $\begin{array}{l}90.1-1980 \\
\text { Base }\end{array}$ & $\begin{array}{c}90.1-1999 \\
\text { Envelope } \\
\text { Only }\end{array}$ & \begin{tabular}{|c|}
$90.1-$ \\
1999 \\
Lighting \\
Only
\end{tabular} & $\begin{array}{l}90.1-1999 \\
\text { Envelope } \\
\text { \& Lighting }\end{array}$ \\
\hline \multicolumn{2}{|c|}{ Small Office (WWR=0.18) } & Normalized Results & Base & \multicolumn{3}{|c|}{ Savings Relative to Base } \\
\hline \multicolumn{2}{|c|}{ Key Characteristics } & Energy Use: & \multirow{7}{*}{$\begin{array}{c}44.0 \\
10.8 \\
\$ 0.92\end{array}$} & \multirow{5}{*}{$\begin{array}{c}1.9 \\
2.0 \\
\$ 0.05 \\
\$ 0.12\end{array}$} & \multirow[b]{2}{*}{5.2} & \multirow[b]{2}{*}{7.1} \\
\hline Floor space & 10,000 & Electricity (kBtu/sqft/yr) & & & & \\
\hline No. of floors & 1 & Nat. Gas (kBtu/sqft/yr) & & & -1.6 & 0.5 \\
\hline Aspect ratio & 2.25 & Energy cost (\$/sqft/yr) & & & $\$ 0.09$ & $\$ 0.14$ \\
\hline Core ratio & 0.44 & Life-cycle cost (\$/sqft) & & & $\$ 0.84$ & $\$ 0.97$ \\
\hline \multirow{2}{*}{$\begin{array}{l}\text { Window-wall ratio } \\
\text { Economizer (?) }\end{array}$} & 0.18 & & & \multirow{2}{*}{$\begin{array}{c}1.2 \\
7.5 \%\end{array}$} & & \multirow[b]{2}{*}{$\begin{array}{c}2.2 \\
9.2 \%\end{array}$} \\
\hline & no & $\begin{array}{r}\text { Savings-to-invest. Ratio } \\
\text { Adjusted IRR }\end{array}$ & & & $\begin{array}{c}4.2 \\
10.9 \%\end{array}$ & \\
\hline \multicolumn{2}{|c|}{ Small Office (WWR=0.38) } & Normalized Results & Base & \multicolumn{3}{|c|}{ Savings Relative to Base } \\
\hline \multicolumn{2}{|c|}{ Key Characteristics } & Energy Use: & \multirow{7}{*}{$\begin{array}{c}45.7 \\
11.6 \\
\$ 0.96\end{array}$} & \multirow{6}{*}{$\begin{array}{c}1.4 \\
-0.5 \\
\$ 0.02 \\
\$ 0.11\end{array}$} & \multirow[b]{2}{*}{5.2} & \multirow[b]{2}{*}{6.6} \\
\hline Floor space & 10,000 & Electricity (kBtu/sqft/yr) & & & & \\
\hline No. of floors & 1 & Nat. Gas (kBtu/sqft/yr) & & & -1.6 & -2.2 \\
\hline Aspect ratio & 2.25 & Energy cost $(\$ / \mathrm{sqft} / \mathrm{yr})$ & & & $\$ 0.09$ & $\$ 0.11$ \\
\hline Core ratio & 0.44 & Life-cycle cost (\$/sqft) & & & $\$ 0.84$ & $\$ 0.94$ \\
\hline \multirow{2}{*}{$\begin{array}{l}\text { Window-wall ratio } \\
\text { Economizer (?) }\end{array}$} & 0.38 & & & & & \multirow[b]{2}{*}{$\begin{array}{c}3.1 \\
10.0 \%\end{array}$} \\
\hline & no & $\begin{array}{r}\text { Savings-to-invest. Ratio } \\
\text { Adjusted IRR }\end{array}$ & & $\begin{array}{c}1.6 \\
8.2 \%\end{array}$ & $\begin{array}{c}4.2 \\
10.9 \%\end{array}$ & \\
\hline \multicolumn{2}{|c|}{ Large Office (WWR=0.18) } & Normalized Results & Base & \multicolumn{3}{|c|}{ Savings Relative to Base } \\
\hline \multicolumn{2}{|c|}{ Key Characteristics } & Energy Use: & \multirow{7}{*}{$\begin{array}{c}42.2 \\
6.2 \\
\$ 0.86\end{array}$} & & & \\
\hline Floor space & 60,000 & Electricity (kBtu/sqft/yr) & & & 4.7 & 6.3 \\
\hline No. of floors & 3 & Nat. Gas (kBtu/sqft/yr) & & 1.2 & -1.1 & 0.2 \\
\hline Aspect ratio & 2.25 & Energy cost (\$/sqft/yr) & & $\$ 0.04$ & $\$ 0.08$ & $\$ 0.12$ \\
\hline Core ratio & 0.59 & Life-cycle cost (\$/sqft) & & $\$ 0.12$ & $\$ 0.77$ & $\$ 0.90$ \\
\hline Window-wall ratio & 0.18 & & & & & \\
\hline Economizer (?) & yes & $\begin{array}{r}\text { Savings-to-invest. Ratio } \\
\text { Adjusted IRR }\end{array}$ & & $\begin{array}{c}1.3 \\
7.8 \%\end{array}$ & $\begin{array}{c}3.9 \\
10.7 \%\end{array}$ & $\begin{array}{c}2.4 \\
9.4 \%\end{array}$ \\
\hline Large Office (WW & $2=0.38)$ & Normalized Results & Base & Savings & Relative & to Base \\
\hline Key Charact & eristics & Energy Use: & & & & \\
\hline Floor space & 60,000 & Electricity (kBtu/sqft/yr) & 43.5 & 1.0 & 4.7 & 5.7 \\
\hline No. of floors & 3 & Nat. Gas (kBtu/sqft/yr) & 6.6 & -0.3 & -1.1 & -1.5 \\
\hline Aspect ratio & 2.25 & Energy cost $(\$ / \mathrm{sqft} / \mathrm{yr})$ & $\$ 0.89$ & $\$ 0.02$ & $\$ 0.08$ & $\$ 0.10$ \\
\hline Core ratio & 0.59 & Life-cycle cost (\$/sqft) & & $\$ 0.08$ & $\$ 0.76$ & $\$ 0.84$ \\
\hline Window-wall ratio & 0.38 & & & & & \\
\hline Economizer (?) & yes & $\begin{array}{r}\text { Savings-to-invest. Ratio } \\
\text { Adjusted IRR }\end{array}$ & & $\begin{array}{c}1.6 \\
8.3 \%\end{array}$ & $\begin{array}{c}3.9 \\
10.7 \%\end{array}$ & $\begin{array}{c}3.1 \\
10.1 \%\end{array}$ \\
\hline
\end{tabular}




\section{Summary of Results by Building}

\begin{tabular}{|c|c|c|c|c|c|c|}
\hline Wall Type: & teel Fra & & & andard Lev & & \\
\hline & & & $\begin{array}{l}90.1-1980 \\
\text { Base }\end{array}$ & $\begin{array}{l}\text { 90.1-1999 } \\
\text { Envelope } \\
\text { Only }\end{array}$ & $\begin{array}{c}90.1- \\
1999 \\
\text { Lighting } \\
\text { Only }\end{array}$ & $\begin{array}{l}\text { 90.1-1999 } \\
\text { Envelope } \\
\text { \& Lighting }\end{array}$ \\
\hline Retail & & Normalized Results & Base & Savings & Relative & to Base \\
\hline Key Charact & eristics & Energy Use: & & & & \\
\hline Floor space & 24,000 & Electricity (kBtu/sqft/yr) & 49.6 & 0.2 & 8.1 & 8.3 \\
\hline No. of floors & 1 & Nat. Gas (kBtu/sqft/yr) & 5.1 & 2.0 & -1.5 & 1.0 \\
\hline Aspect ratio & 2.50 & Energy cost $(\$ /$ sqft $/ \mathrm{yr})$ & $\$ 0.99$ & $\$ 0.02$ & $\$ 0.15$ & $\$ 0.17$ \\
\hline Core ratio & 0.61 & Life-cycle cost ( $\$ / \mathrm{sqft})$ & & $-\$ 0.11$ & $\$ 1.56$ & $\$ 1.50$ \\
\hline Window-wall ratio & 0.07 & & & & & \\
\hline Economizer (?) & no & $\begin{array}{r}\text { Savings-to-invest. Ratio } \\
\text { Adjusted IRR }\end{array}$ & & $\begin{array}{c}0.7 \\
5.9 \%\end{array}$ & $\begin{array}{c}7.4 \\
12.5 \%\end{array}$ & $\begin{array}{c}3.6 \\
10.5 \%\end{array}$ \\
\hline Education (elemer & tary) & Normalized Results & Base & Savings & Relative & to Base \\
\hline Key Charact & eristics & Energy Use: & & & & \\
\hline Floor space & 50,000 & Electricity (kBtu/sqft/yr) & 30.0 & 1.2 & 3.5 & 4.8 \\
\hline No. of floors & 1 & Nat. Gas (kBtu/sqft/yr) & 23.2 & 1.6 & -1.6 & 0.0 \\
\hline Aspect ratio & 6.00 & Energy cost (\$/sqft/yr) & $\$ 0.74$ & $\$ 0.03$ & $\$ 0.06$ & $\$ 0.09$ \\
\hline Core ratio & 0.63 & Life-cycle cost (\$/sqft) & & $\$ 0.07$ & $\$ 0.47$ & $\$ 0.54$ \\
\hline Window-wall ratio & 0.18 & & & & & \\
\hline Economizer (?) & no & $\begin{array}{r}\text { Savings-to-invest. Ratio } \\
\text { Adjusted IRR }\end{array}$ & & $\begin{array}{c}1.2 \\
7.5 \%\end{array}$ & $\begin{array}{c}3.0 \\
9.9 \%\end{array}$ & $\begin{array}{c}1.9 \\
8.7 \%\end{array}$ \\
\hline Education (two-st & pry) & Normalized Results & Base & Savings & Relative & to Base \\
\hline Key Charact & eristics & Energy Use: & & & & \\
\hline Floor space & 80,000 & Electricity (kBtu/sqft/yr) & 31.7 & 1.7 & 3.6 & 5.3 \\
\hline No. of floors & 2 & Nat. Gas (kBtu/sqft/yr) & 20.4 & 1.4 & -1.5 & -0.1 \\
\hline Aspect ratio & 5.00 & Energy cost (\$/sqft/yr) & $\$ 0.75$ & $\$ 0.04$ & $\$ 0.06$ & $\$ 0.10$ \\
\hline Core ratio & 0.62 & Life-cycle cost (\$/sqft) & & $\$ 0.19$ & $\$ 0.50$ & $\$ 0.69$ \\
\hline Window-wall ratio & 0.18 & & & & & \\
\hline Economizer (?) & no & $\begin{array}{r}\text { Savings-to-invest. Ratio } \\
\text { Adjusted IRR }\end{array}$ & & $\begin{array}{c}1.5 \\
8.2 \%\end{array}$ & $\begin{array}{c}3.1 \\
10.1 \%\end{array}$ & $\begin{array}{c}2.2 \\
9.1 \%\end{array}$ \\
\hline
\end{tabular}




\section{APPENDIX B \\ Mass Wall Results \\ 90.1-1980 Envelope Baseline}




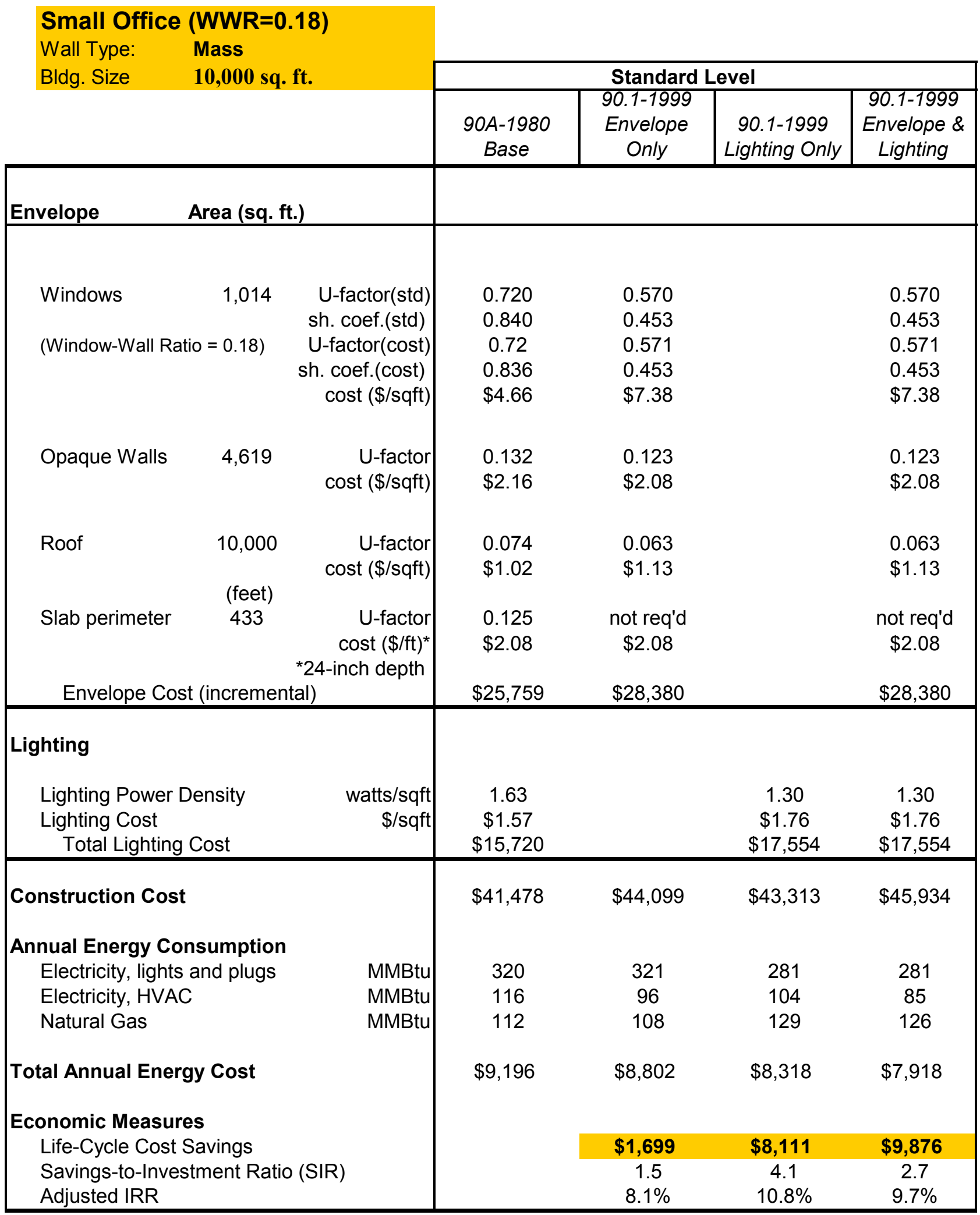

Notes:

1 No economizer used

22001 electricity price $=6.6 \mathrm{cents} / \mathrm{kWh} \quad 2001$ gas price $=\$ 6.71 / \mathrm{MMBtu}$

3 Years for Analysis $=40 \quad$ Discount Rate $=\mathbf{7 . 0 \%}$

Life-cycle cost savings includes replacement costs and residual values 


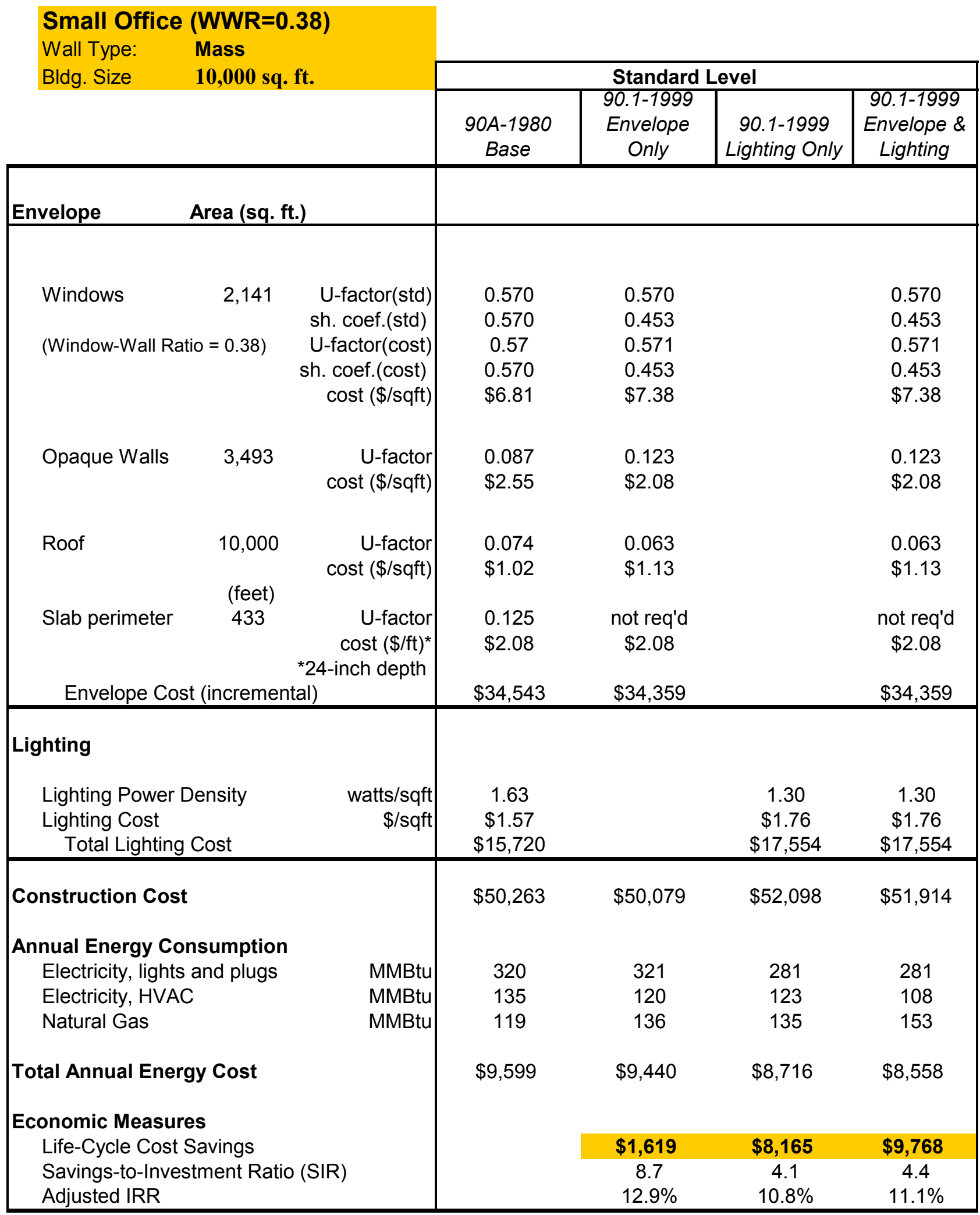

Notes:

1 No economizer used

22001 electricity price $=6.6 \mathrm{cents} / \mathrm{kWh} \quad 2001$ gas price $=\$ 6.71 / \mathrm{MMBtu}$

3 Years for Analysis $=40 \quad$ Discount Rate $=\mathbf{7 . 0 \%}$

Life-cycle cost savings includes replacement costs and residual values 


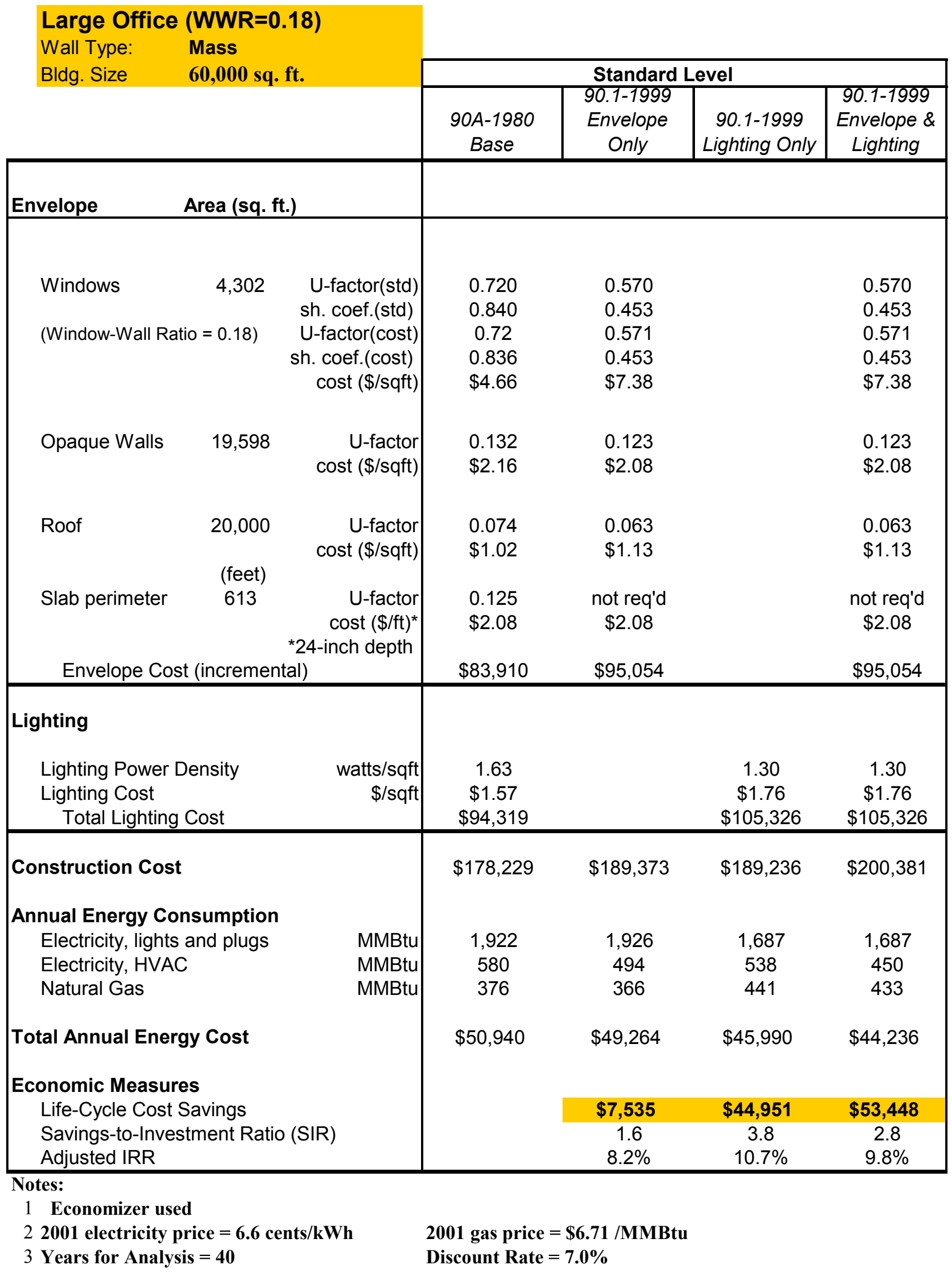

Life-cycle cost savings includes replacement costs and residual values 


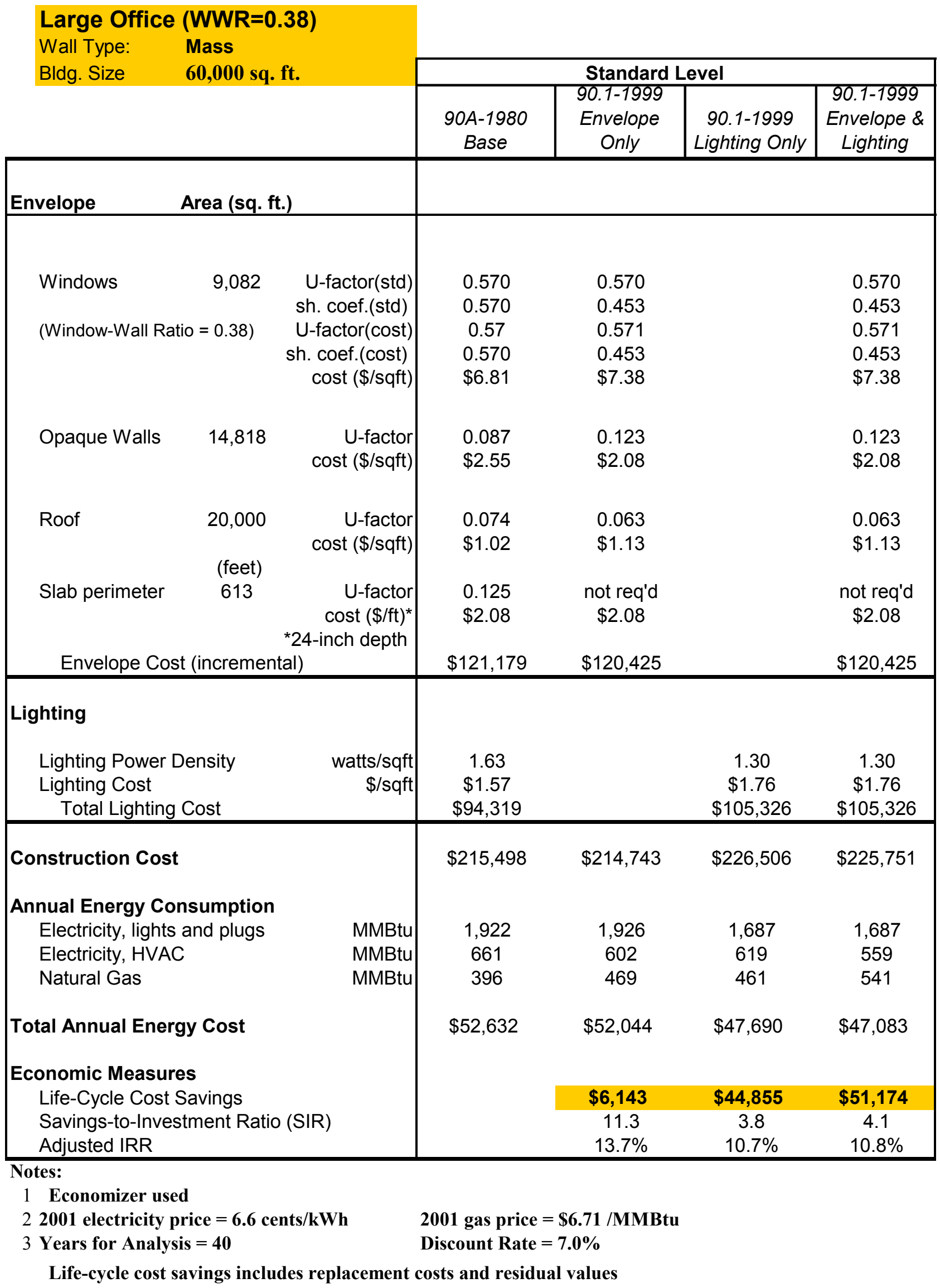




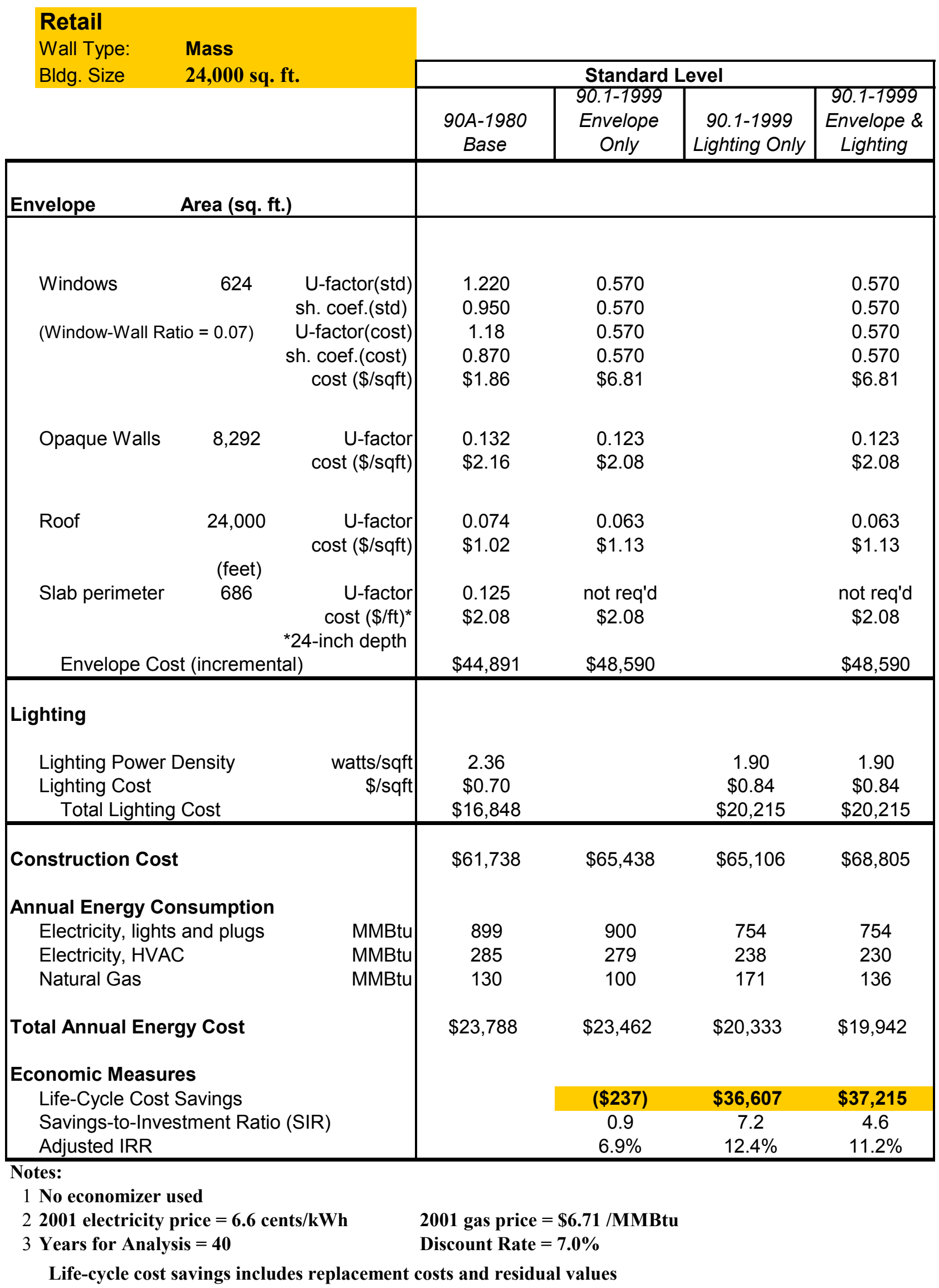




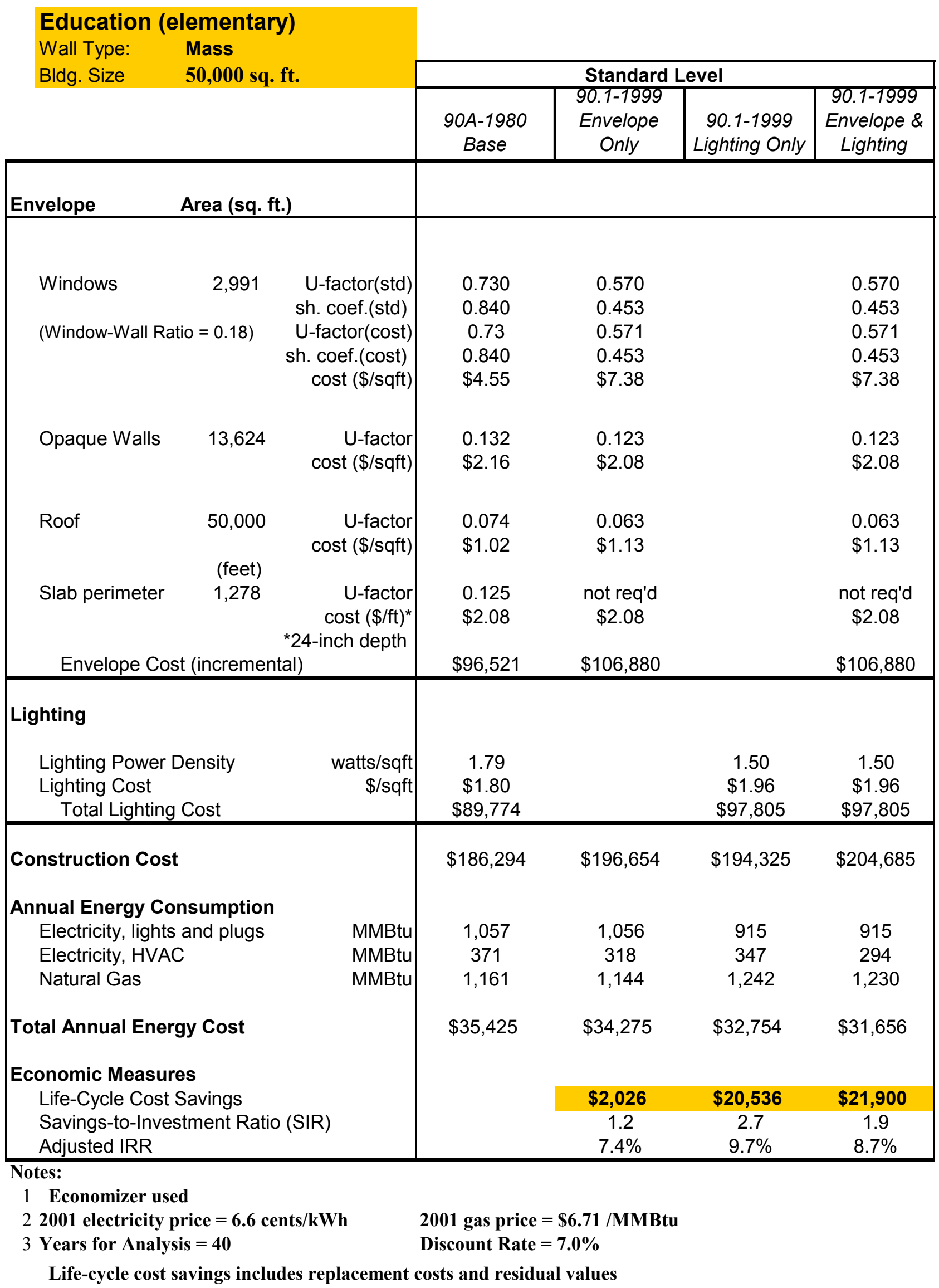




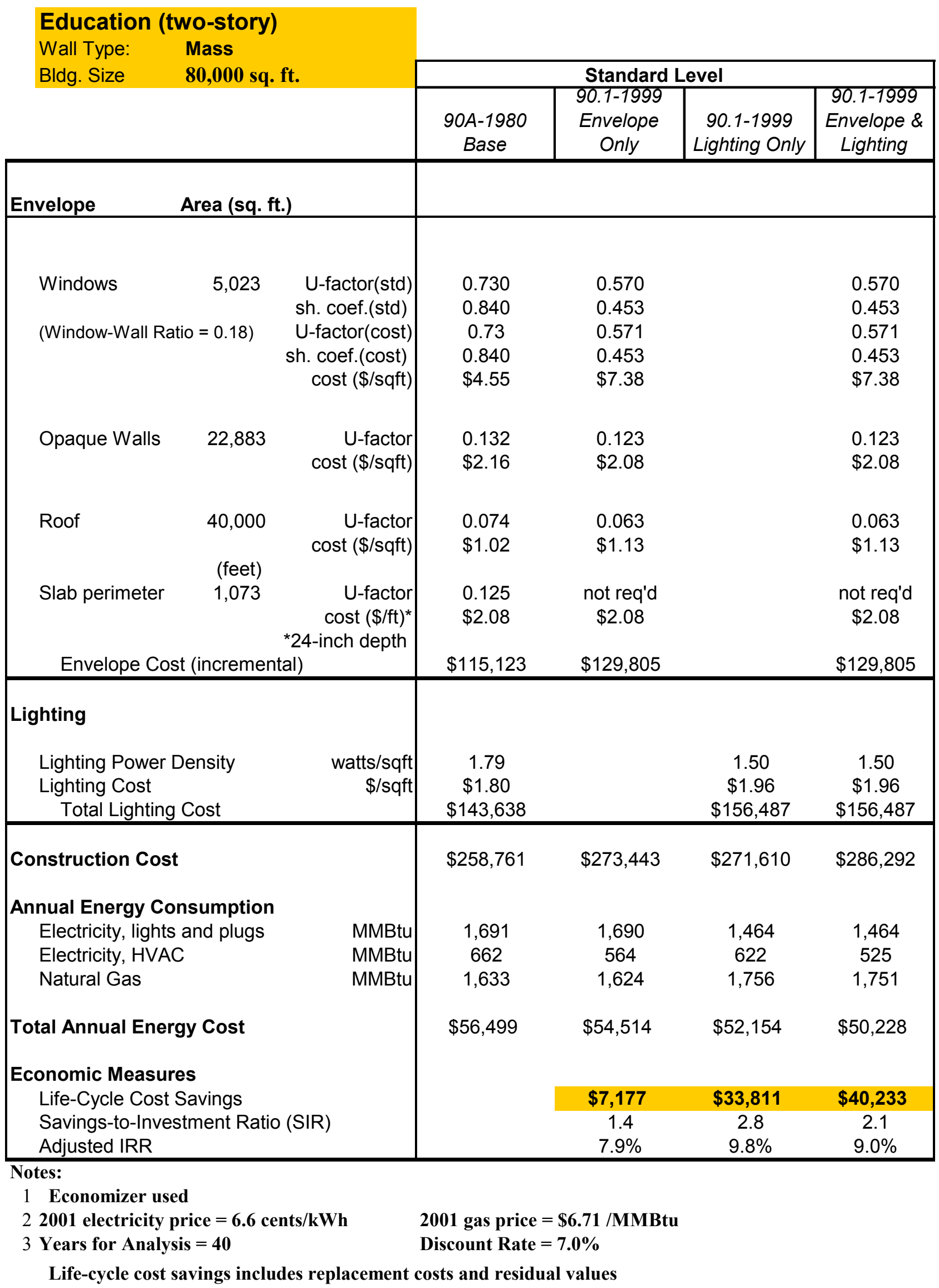




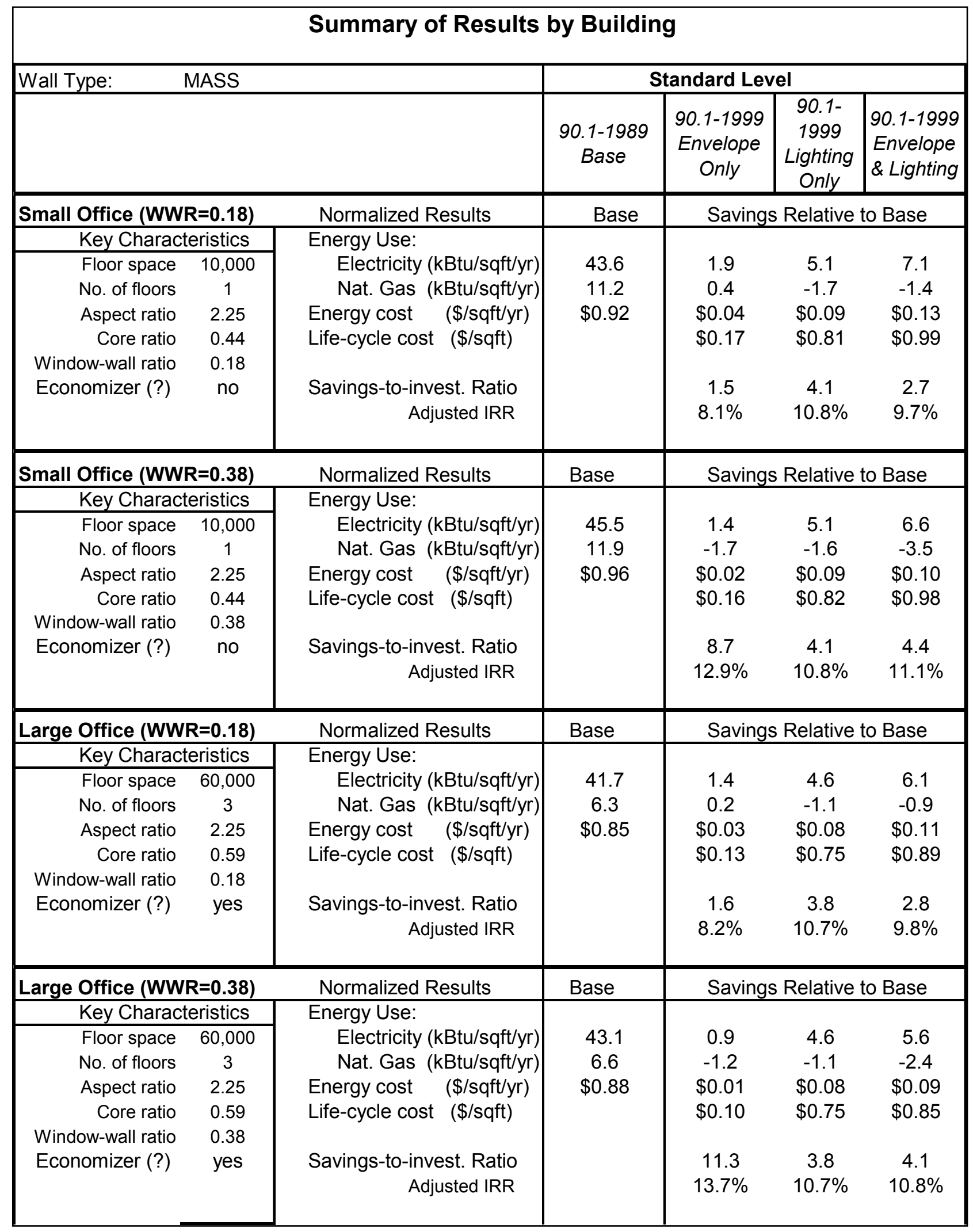




\section{Summary of Results by Building}

\begin{tabular}{|c|c|c|c|c|c|c|}
\hline Wall Type: & MASS & & & andard Le & & \\
\hline & & & $\begin{array}{l}90.1-1989 \\
\text { Base }\end{array}$ & $\begin{array}{c}90.1-1999 \\
\text { Envelope } \\
\text { Only }\end{array}$ & $\begin{array}{c}\text { 90.1- } \\
1999 \\
\text { Lighting } \\
\text { Only }\end{array}$ & $\begin{array}{l}90.1-1999 \\
\text { Envelope } \\
\text { \& Lighting }\end{array}$ \\
\hline Retail & & Normalized Results & Base & Saving & Relative & o Base \\
\hline Key Charac & eristics & Energy Use: & & & & \\
\hline Floor space & 24,000 & Electricity (kBtu/sqft/yr) & 49.4 & 0.3 & 8.0 & 8.4 \\
\hline No. of floors & 1 & Nat. Gas (kBtu/sqft/yr) & 5.4 & 1.2 & -1.7 & -0.2 \\
\hline Aspect ratio & 2.50 & Energy cost $\quad(\$ /$ sqft/yr $)$ & $\$ 0.99$ & $\$ 0.01$ & $\$ 0.14$ & $\$ 0.16$ \\
\hline Core ratio & 0.61 & Life-cycle cost (\$/sqft) & & $-\$ 0.01$ & $\$ 1.53$ & $\$ 1.55$ \\
\hline Window-wall ratio & 0.07 & & & & & \\
\hline Economizer (?) & no & $\begin{array}{r}\text { Savings-to-invest. Ratio } \\
\text { Adjusted IRR }\end{array}$ & & $\begin{array}{c}0.9 \\
6.9 \%\end{array}$ & $\begin{array}{c}7.2 \\
12.4 \%\end{array}$ & $\begin{array}{c}4.6 \\
11.2 \%\end{array}$ \\
\hline Education (eleme & tary) & Normalized Results & Base & Saving & Relative & to Base \\
\hline Key Charac & eristics & Energy Use: & & & & \\
\hline Floor space & 50,000 & Electricity (kBtu/sqft/yr) & 28.6 & 1.1 & 3.3 & 4.4 \\
\hline No. of floors & 1 & Nat. Gas (kBtu/sqft/yr) & 23.2 & 0.3 & -1.6 & -1.4 \\
\hline Aspect ratio & 6.00 & Energy cost $\quad(\$ /$ sqft/yr $)$ & $\$ 0.71$ & $\$ 0.02$ & $\$ 0.05$ & $\$ 0.08$ \\
\hline Core ratio & 0.63 & Life-cycle cost (\$/sqft) & & $\$ 0.04$ & $\$ 0.41$ & $\$ 0.44$ \\
\hline Window-wall ratio & 0.18 & & & & & \\
\hline Economizer (?) & yes & $\begin{array}{r}\text { Savings-to-invest. Ratio } \\
\text { Adjusted IRR }\end{array}$ & & $\begin{array}{c}1.2 \\
7.4 \%\end{array}$ & $\begin{array}{c}2.7 \\
9.7 \%\end{array}$ & $\begin{array}{c}1.9 \\
8.7 \%\end{array}$ \\
\hline Education (two-st & ory) & Normalized Results & Base & Saving & Relative & o Base \\
\hline Key Charac & eristics & Energy Use: & & & & \\
\hline Floor space & 80,000 & Electricity (kBtu/sqft/yr) & 29.4 & 1.2 & 3.3 & 4.6 \\
\hline No. of floors & 2 & Nat. Gas (kBtu/sqft/yr) & 20.4 & 0.1 & -1.5 & -1.5 \\
\hline Aspect ratio & 5.00 & Energy cost $\quad(\$ /$ sqft/yr $)$ & $\$ 0.71$ & $\$ 0.02$ & $\$ 0.05$ & $\$ 0.08$ \\
\hline Core ratio & 0.62 & Life-cycle cost (\$/sqft) & & $\$ 0.09$ & $\$ 0.42$ & $\$ 0.50$ \\
\hline Window-wall ratio & 0.18 & & & & & \\
\hline Economizer (?) & yes & $\begin{array}{r}\text { Savings-to-invest. Ratio } \\
\text { Adjusted IRR }\end{array}$ & & $\begin{array}{c}1.4 \\
7.9 \%\end{array}$ & $\begin{array}{c}2.8 \\
9.8 \%\end{array}$ & $\begin{array}{c}2.1 \\
9.0 \%\end{array}$ \\
\hline
\end{tabular}


APPENDIX C

Metal Frame Results

90.1-1989 Baseline 


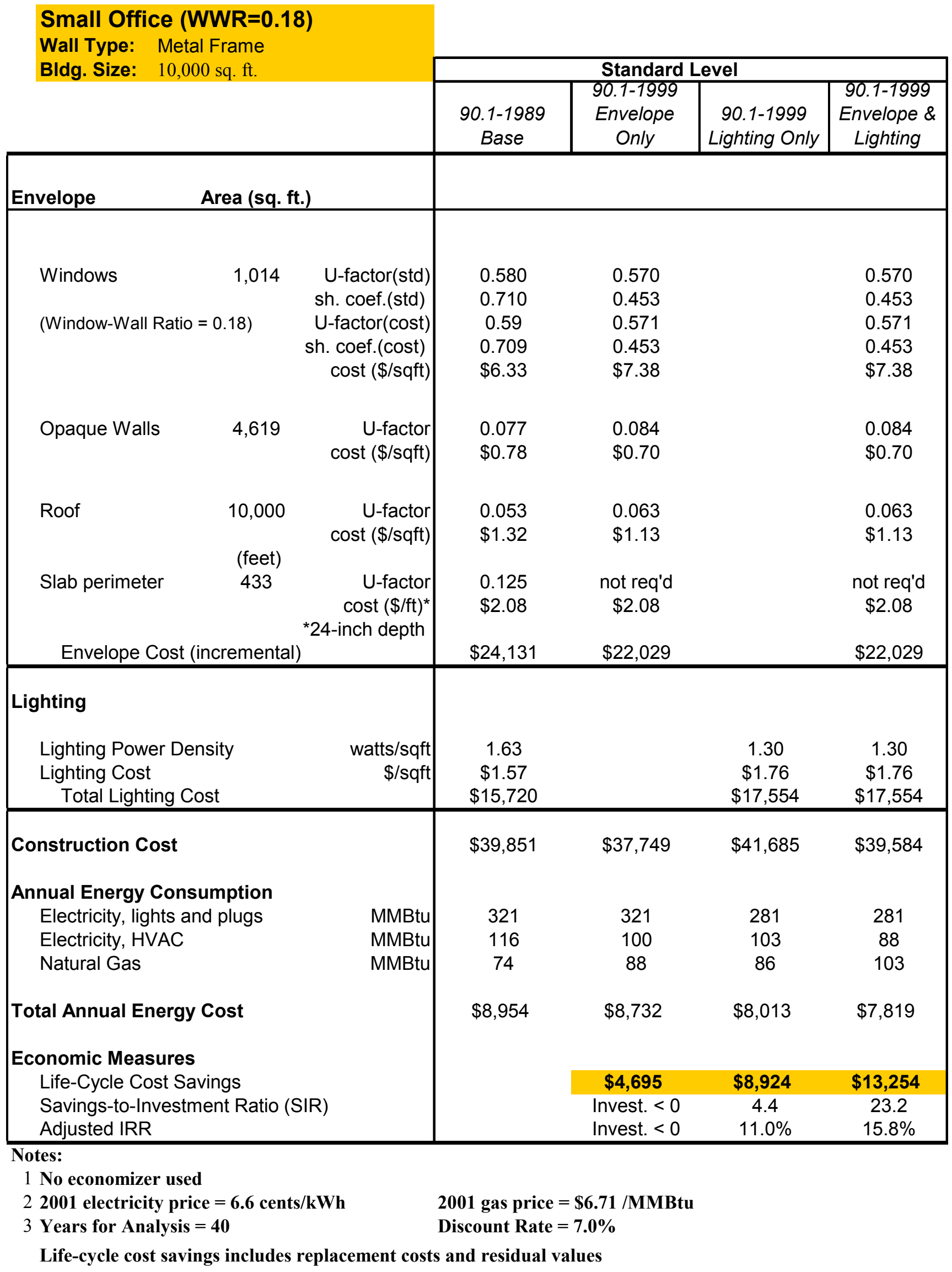




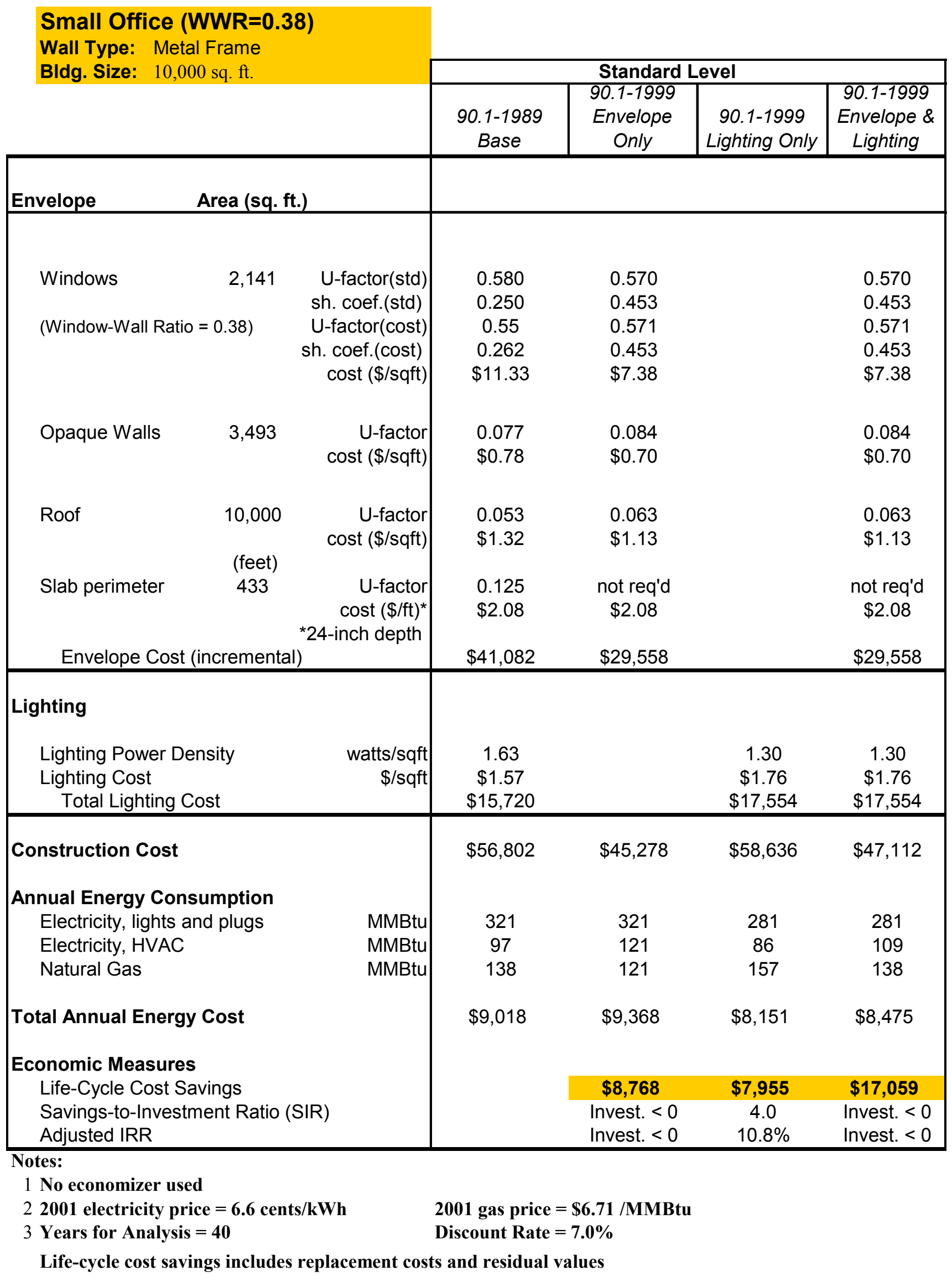




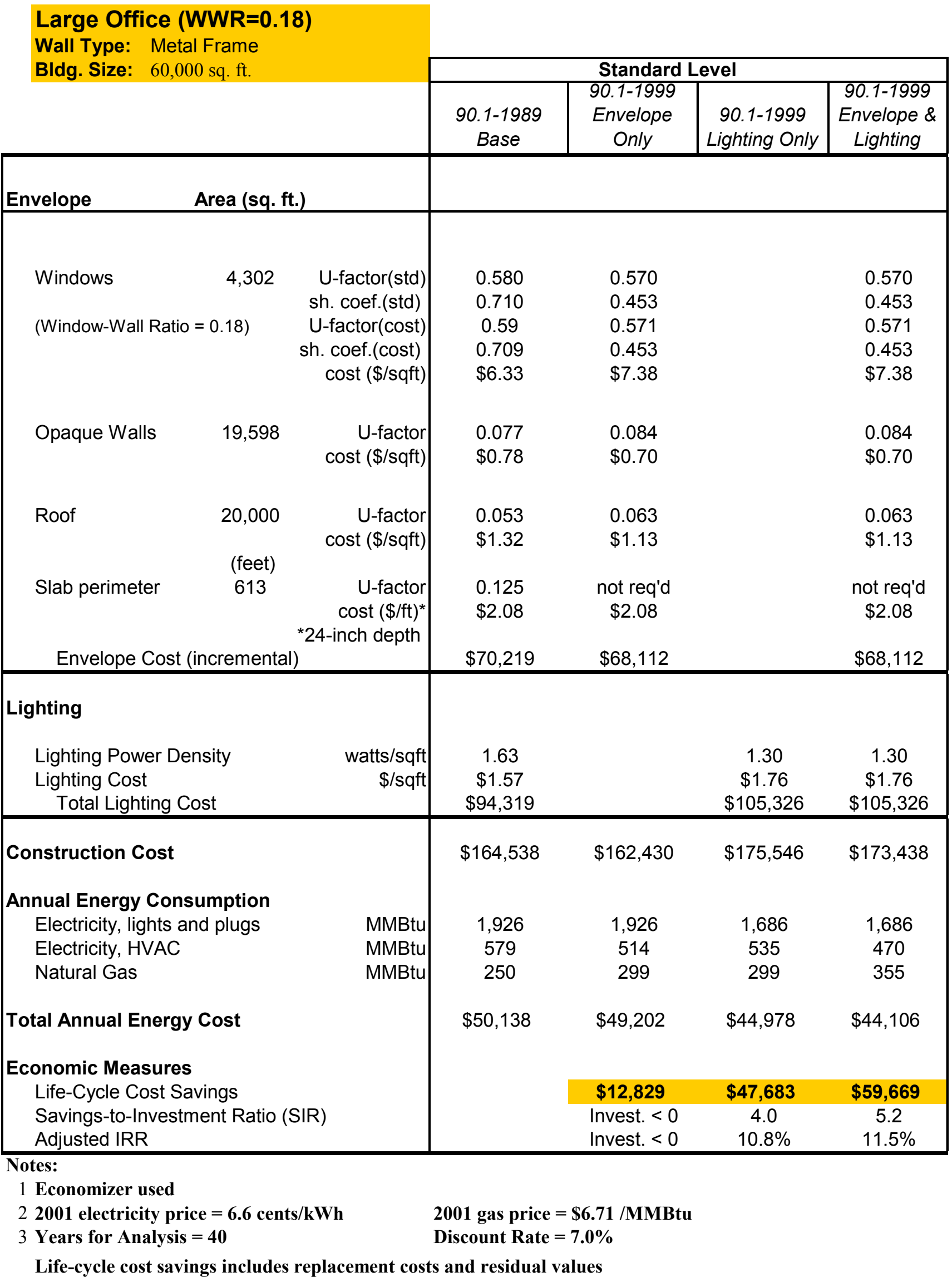


Large Office (WWR=0.38)

Wall Type: Metal Frame

Bldg. Size: 60,000 sq. ft.

Standard Level

\begin{tabular}{|c|c|c|c|}
\hline \multicolumn{4}{|c|}{ Standard Level } \\
\hline & $90.1-1999$ & $90.1-1999$ \\
$90.1-1989$ & Envelope & $90.1-1999$ & $\begin{array}{c}\text { Envelope \& } \\
\text { Base }\end{array}$ \\
Only & Lighting Only & Lighting \\
\hline
\end{tabular}

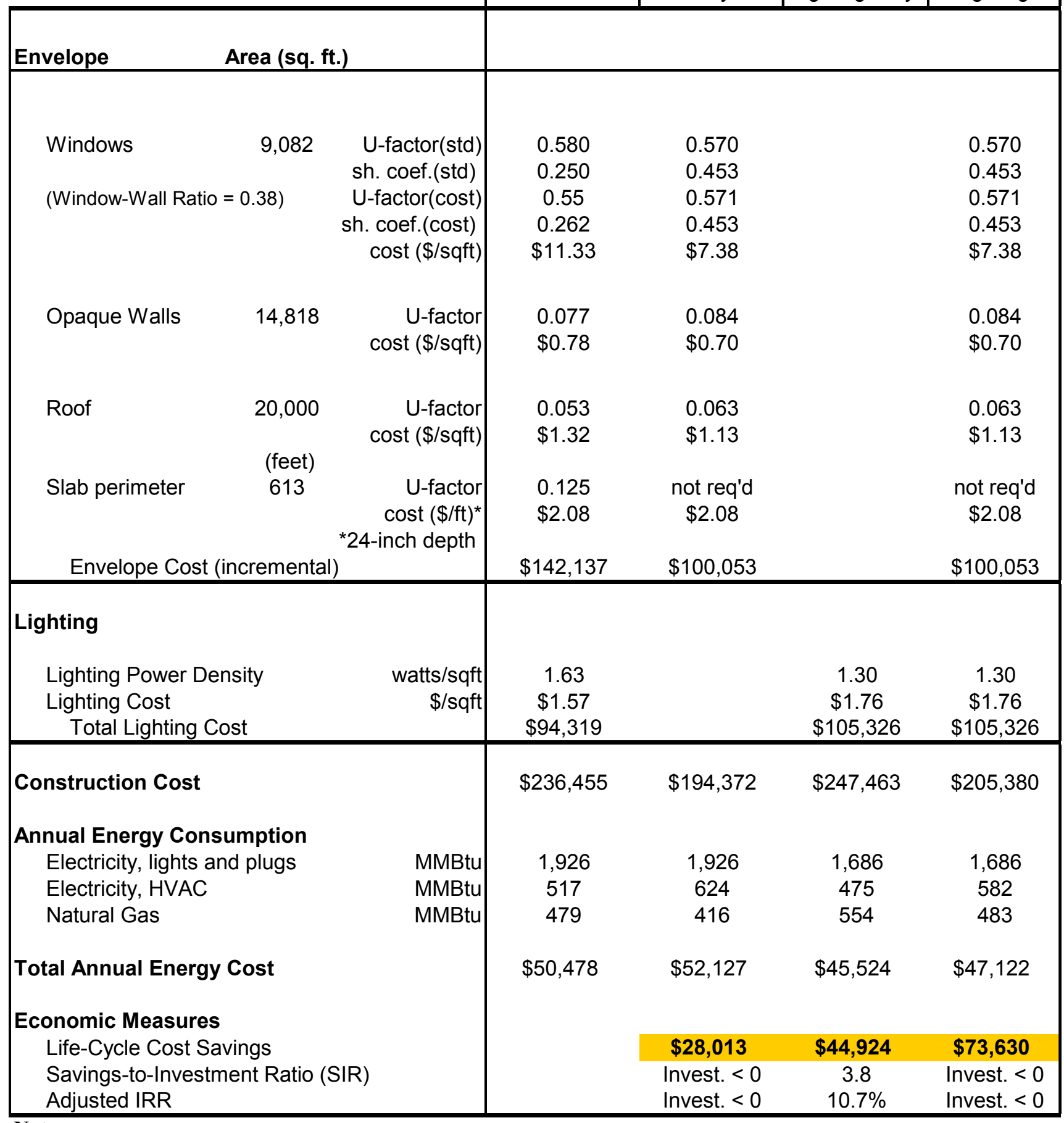

\section{Notes:}

1 Economizer used

22001 electricity price $=6.6$ cents $/ \mathbf{k W h} \quad 2001$ gas price $=\$ 6.71 / \mathrm{MMBtu}$

3 Years for Analysis $=40 \quad$ Discount Rate $=\mathbf{7 . 0 \%}$

Life-cycle cost savings includes replacement costs and residual values 


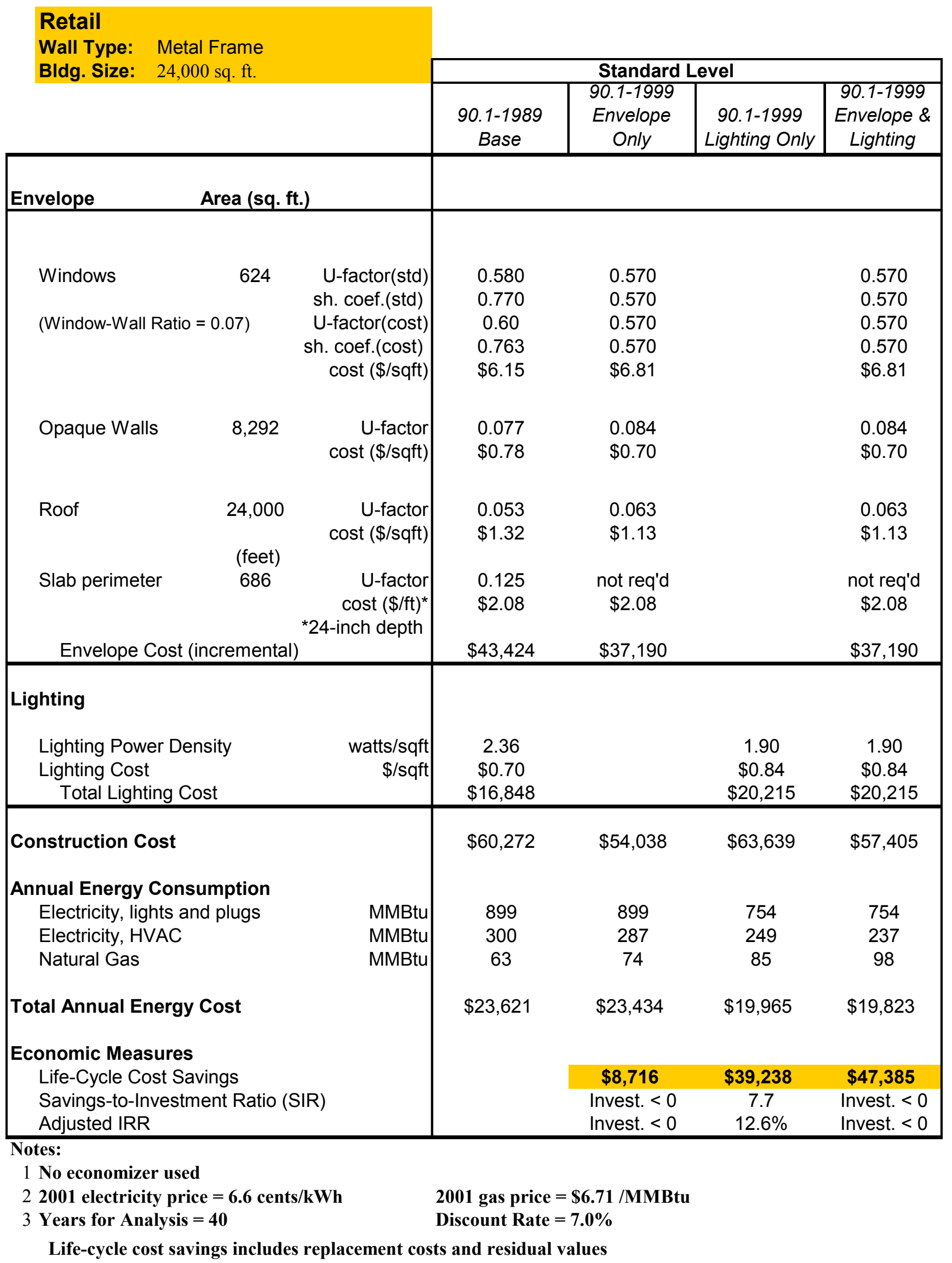




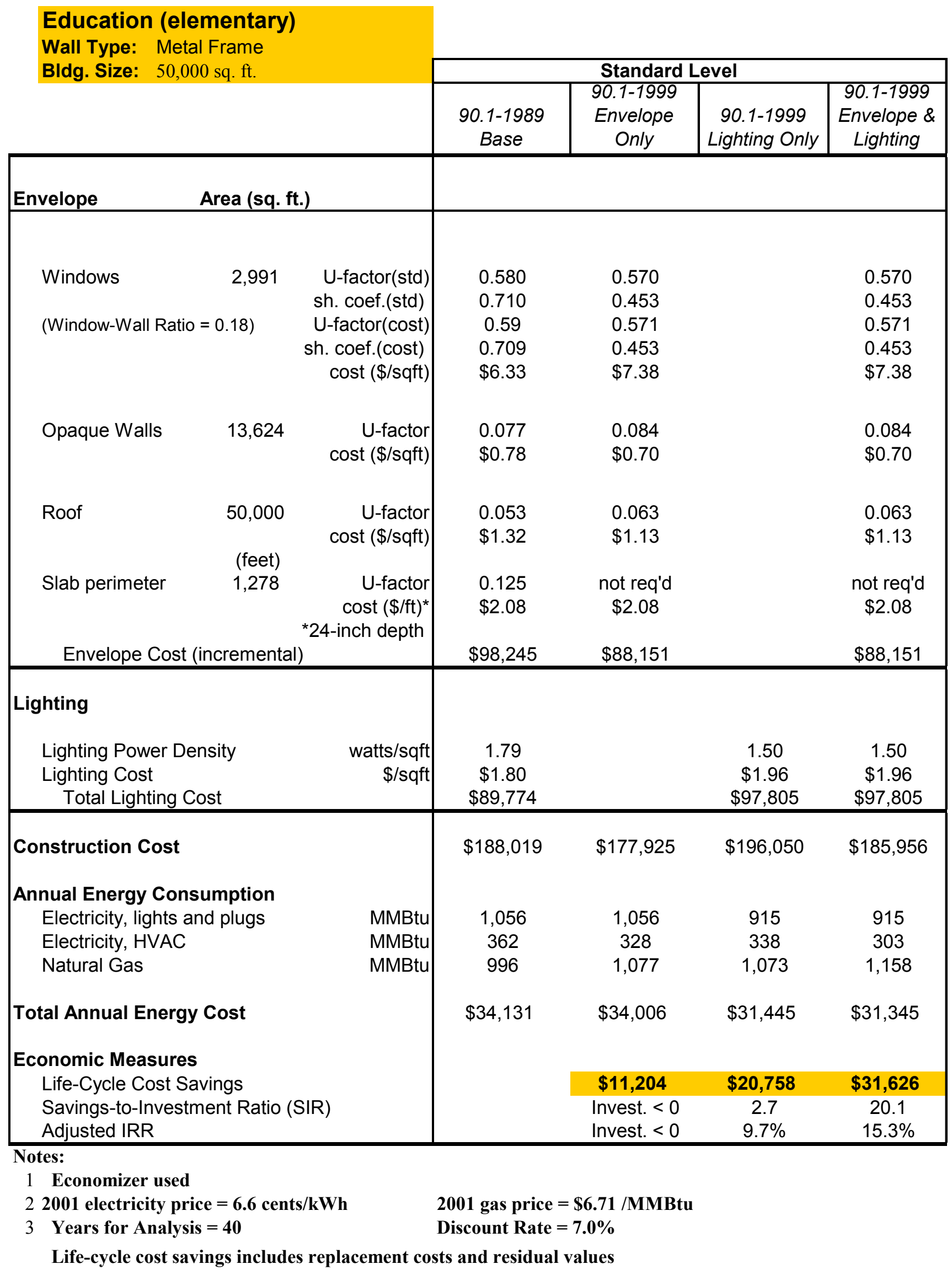


Bldg. Size: 80,000 sq. ft.

\begin{tabular}{|c|c|c|c|}
\hline \multicolumn{4}{|c|}{ Standard Level } \\
\hline $\begin{array}{c}90.1-1999 \\
\text { Base }\end{array}$ & $\begin{array}{c}\text { Envelope } \\
\text { Only }\end{array}$ & $\begin{array}{c}90.1-1999 \\
\text { Lighting Only }\end{array}$ & $\begin{array}{c}\text { Envelope \& } \\
\text { Lighting }\end{array}$ \\
\hline
\end{tabular}

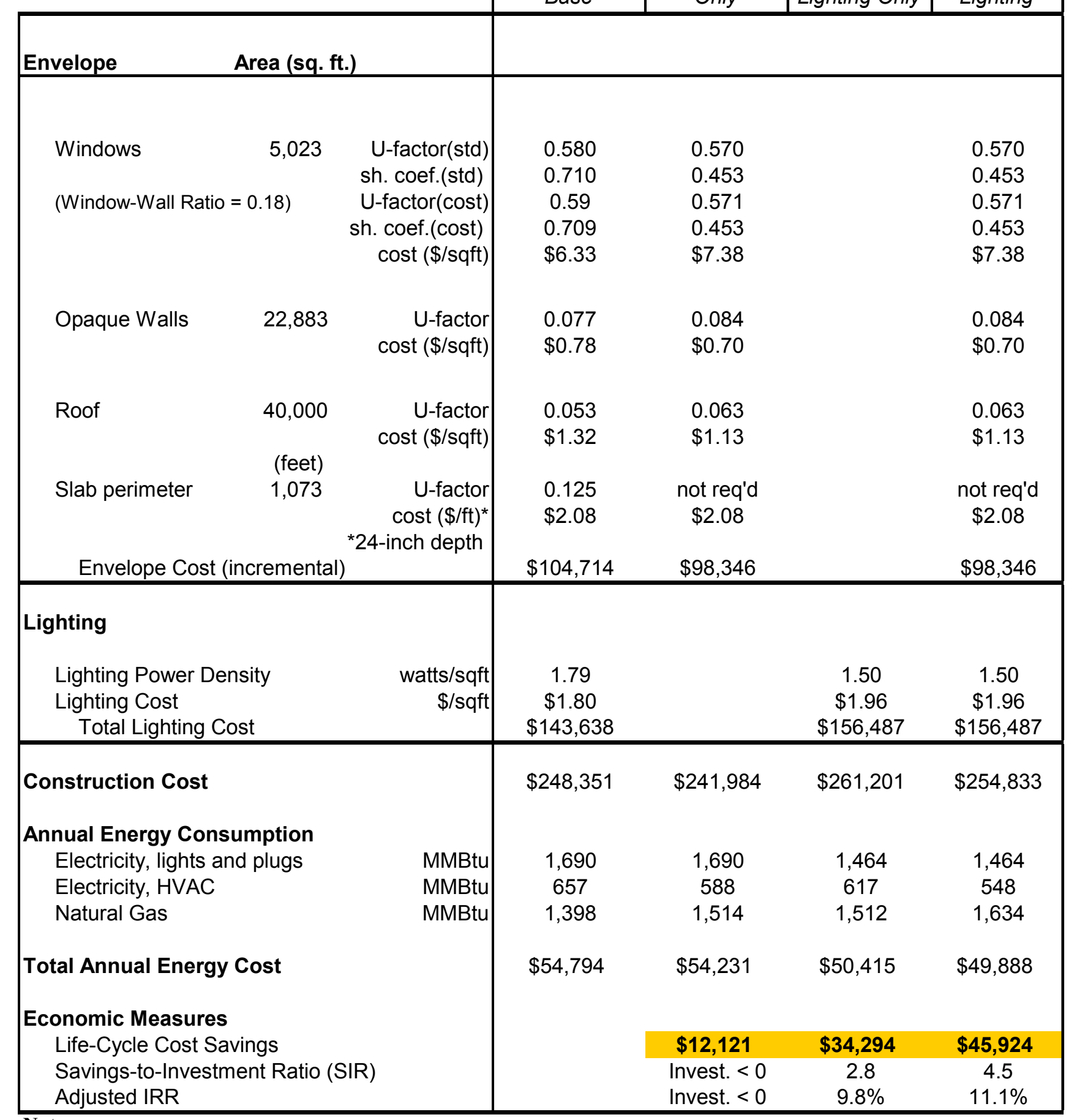

Notes:

1 Economizer used

22001 electricity price $=6.6$ cents $/ \mathbf{k W h} \quad 2001$ gas price $=\$ \mathbf{\$ 6 . 7 1} / \mathrm{MMBtu}$

3 Years for Analysis $=40 \quad$ Discount Rate $=\mathbf{7 . 0 \%}$

Life-cycle cost savings includes replacement costs and residual values 
Summary of Results by Building (Office Buildings)

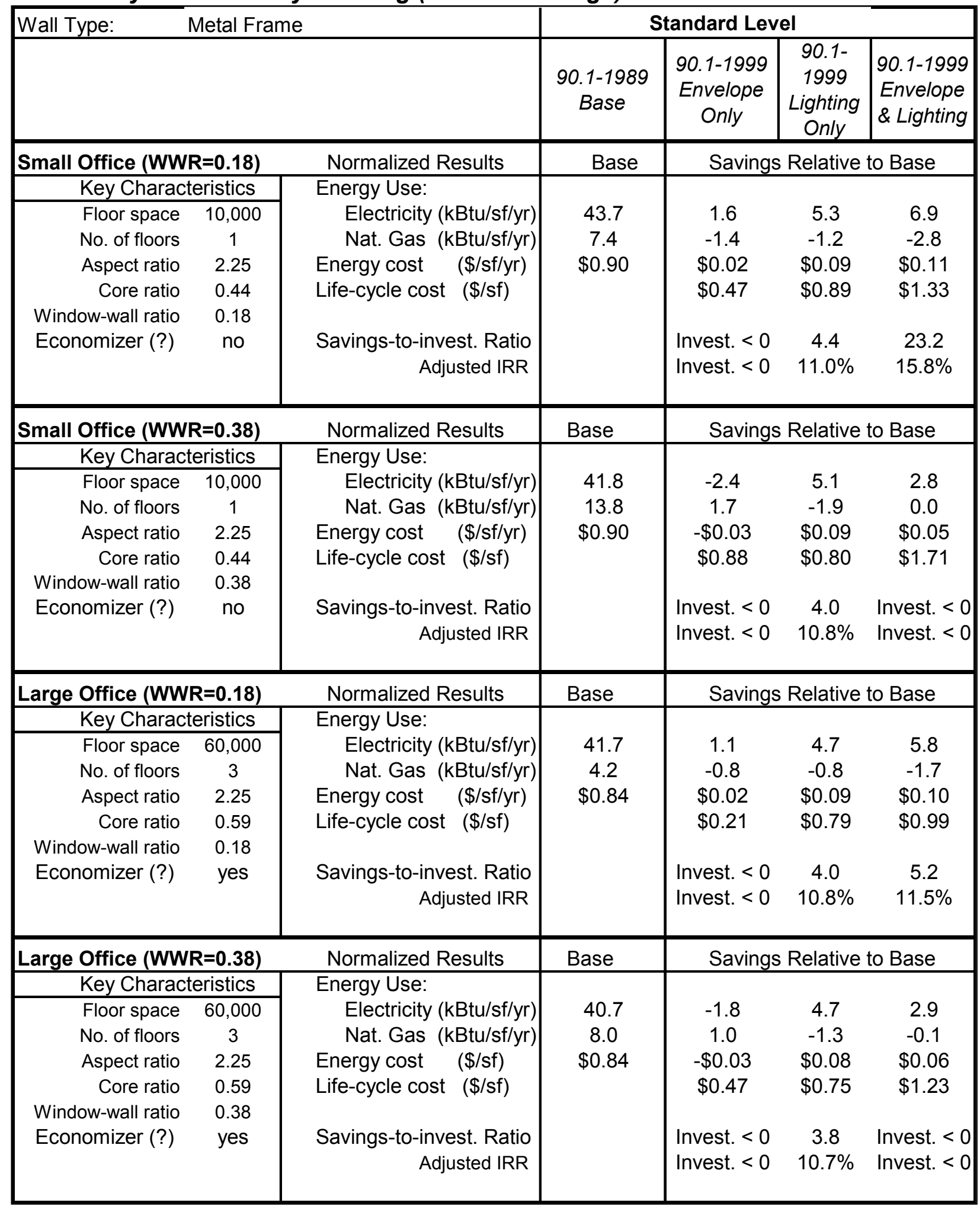


Summary of Results by Building (Retail and Education Buildings)

\begin{tabular}{|c|c|c|c|c|c|c|}
\hline \multirow{2}{*}{\multicolumn{3}{|c|}{$\begin{array}{ll} & \\
\text { Wall Type: } \quad \text { Metal Frame }\end{array}$}} & \multicolumn{4}{|c|}{ Standard Level } \\
\hline & & & \multirow{2}{*}{$\begin{array}{c}\text { 90.1-1989 } \\
\text { Base } \\
\text { Base }\end{array}$} & $\begin{array}{c}\text { 90.1-1999 } \\
\text { Envelope } \\
\text { Only }\end{array}$ & \begin{tabular}{|c|}
$90.1-$ \\
1999 \\
Lighting \\
Only
\end{tabular} & $\begin{array}{l}90.1-1999 \\
\text { Envelope } \\
\text { \& Lighting }\end{array}$ \\
\hline Retail & & Normalized Results & & \multicolumn{3}{|c|}{ Savings Relative to Base } \\
\hline \multicolumn{2}{|c|}{ Key Characteristics } & Energy Use: & \multirow{7}{*}{$\begin{array}{c}50.0 \\
2.6 \\
\$ 0.98\end{array}$} & & & \\
\hline Floor space & 24,000 & Electricity (kBtu/sf/yr) & & 0.6 & 8.2 & 8.7 \\
\hline No. of floors & 1 & Nat. Gas (kBtu/sf/yr) & & -0.4 & -0.9 & -1.4 \\
\hline Aspect ratio & 2.50 & Energy cost $\quad(\$ / \mathrm{sf} / \mathrm{yr})$ & & $\$ 0.01$ & $\$ 0.15$ & $\$ 0.16$ \\
\hline Core ratio & 0.61 & Life-cycle cost (\$/sf) & & $\$ 0.36$ & $\$ 1.63$ & $\$ 1.97$ \\
\hline Window-wall ratio & 0.07 & & & & & \\
\hline Economizer (?) & no & $\begin{array}{r}\text { Savings-to-invest. Ratio } \\
\text { Adjusted IRR }\end{array}$ & & $\begin{array}{l}\text { Invest. }<0 \\
\text { Invest. }<0\end{array}$ & $\begin{array}{c}7.7 \\
12.6 \%\end{array}$ & $\begin{array}{l}\text { Invest. }<0 \\
\text { Invest. }<0\end{array}$ \\
\hline \multicolumn{2}{|c|}{ Education (elementary) } & Normalized Results & Base & \multicolumn{3}{|c|}{ Savings Relative to Base } \\
\hline \multicolumn{2}{|c|}{ Key Characteristics } & Energy Use: & \multirow{8}{*}{$\begin{array}{c}28.4 \\
19.9 \\
\$ 0.68\end{array}$} & & & \\
\hline Floor space & 50,000 & Electricity (kBtu/sf/yr) & & 0.7 & 3.3 & 4.0 \\
\hline No. of floors & 1 & Nat. Gas (kBtu/sf/yr) & & -1.6 & -1.5 & -3.2 \\
\hline Aspect ratio & 6.00 & Energy cost $\quad(\$ / s f / y r)$ & & $\$ 0.00$ & $\$ 0.05$ & $\$ 0.06$ \\
\hline Core ratio & 0.63 & Life-cycle cost (\$/sf) & & $\$ 0.22$ & $\$ 0.42$ & $\$ 0.63$ \\
\hline Window-wall ratio & 0.18 & & & & & \\
\hline Economizer (?) & yes & Savings-to-invest. Ratio & & Invest. $<0$ & 2.7 & 20.1 \\
\hline & & Adjusted IRR & & Invest. $<0$ & $9.7 \%$ & $15.3 \%$ \\
\hline \multicolumn{2}{|c|}{ Education (two-story) } & Normalized Results & Base & \multicolumn{3}{|c|}{ Savings Relative to Base } \\
\hline \multicolumn{2}{|c|}{ Key Characteristics } & Energy Use: & \multirow{8}{*}{$\begin{array}{c}29.3 \\
17.5 \\
\$ 0.68\end{array}$} & \multirow{5}{*}{$\begin{array}{c}0.9 \\
-1.4 \\
\$ 0.01 \\
\$ 0.15\end{array}$} & \multirow[b]{2}{*}{3.3} & \multirow[b]{2}{*}{4.2} \\
\hline Floor space & 80,000 & Electricity (kBtu/sf/yr) & & & & \\
\hline No. of floors & 2 & Nat. Gas (kBtu/sf/yr) & & & -1.4 & -2.9 \\
\hline Aspect ratio & 5.00 & Energy cost $\quad(\$ /$ sf/yr $)$ & & & $\$ 0.05$ & $\$ 0.06$ \\
\hline Core ratio & 0.62 & Life-cycle cost (\$/sf) & & & $\$ 0.43$ & $\$ 0.57$ \\
\hline \multirow{3}{*}{$\begin{array}{l}\text { Window-wall ratio } \\
\text { Economizer (?) }\end{array}$} & 0.18 & & & & & \\
\hline & yes & Savings-to-invest. Ratio & & Invest. $<0$ & 2.8 & 4.5 \\
\hline & & Adjusted IRR & & Invest. $<0$ & $9.8 \%$ & $11.1 \%$ \\
\hline
\end{tabular}




\section{APPENDIX C \\ Mass Wall Results \\ 90.1-1989 Baseline}




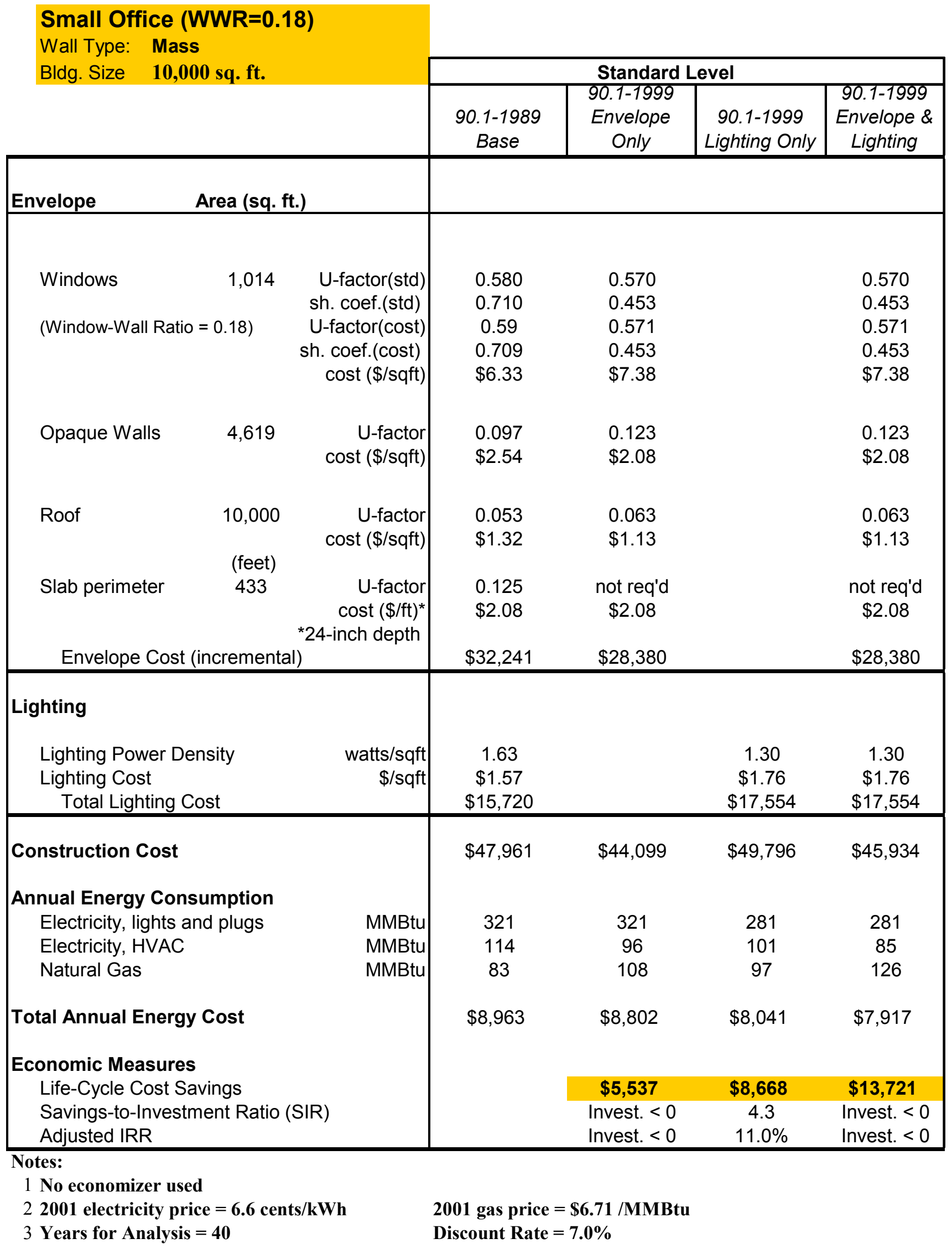

Life-cycle cost savings includes replacement costs and residual values 


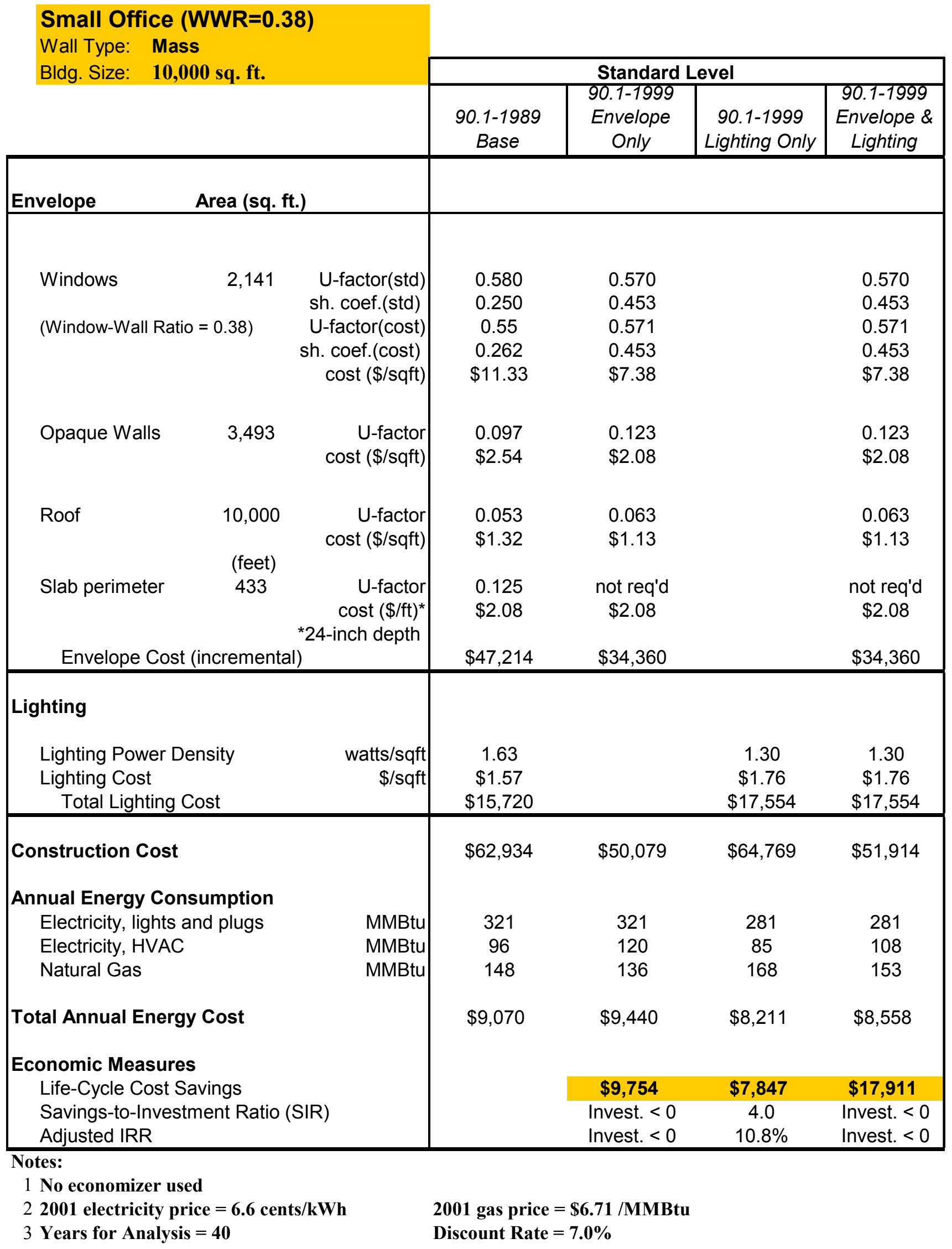

Life-cycle cost savings includes replacement costs and residual values 


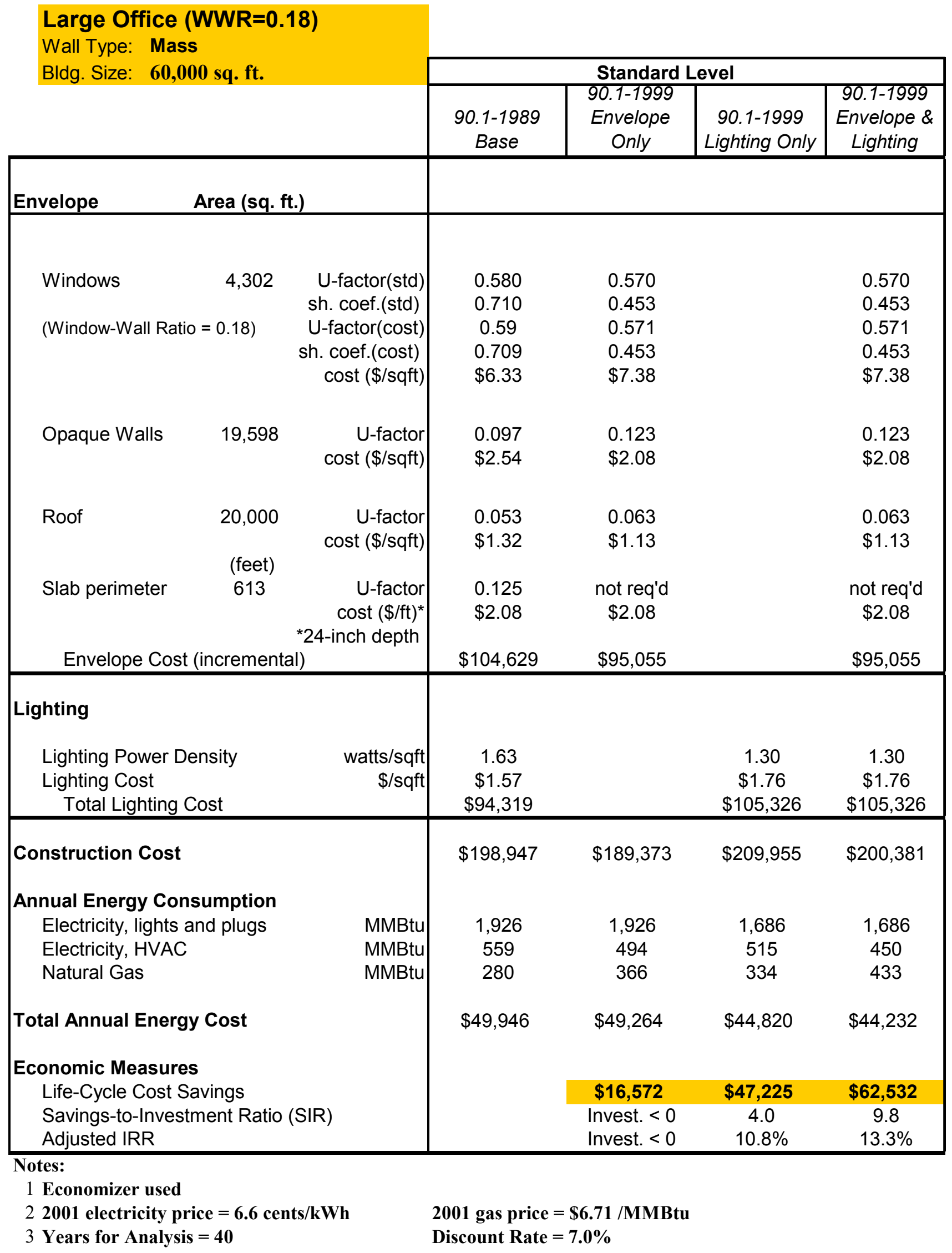

Life-cycle cost savings includes replacement costs and residual values 


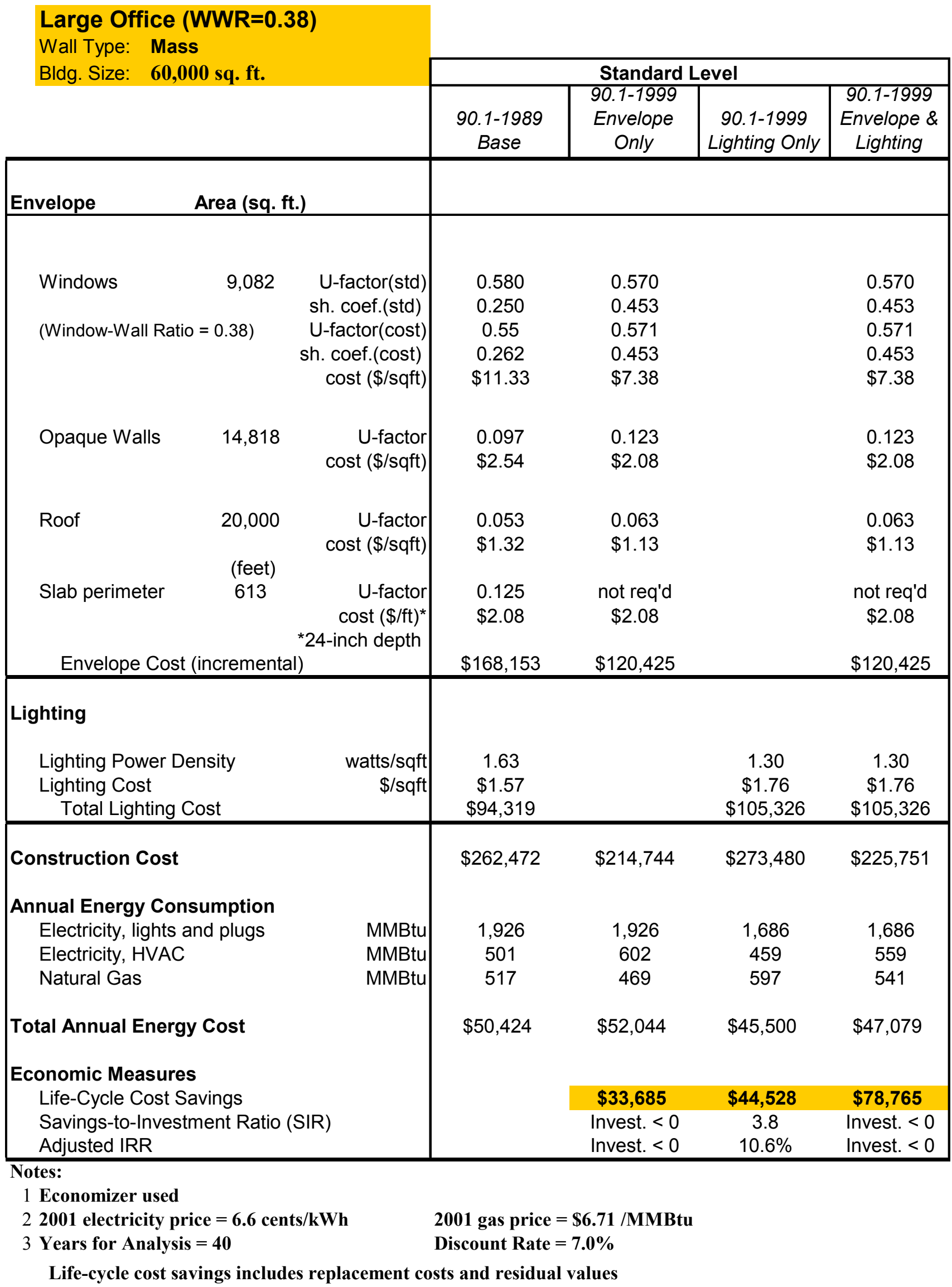




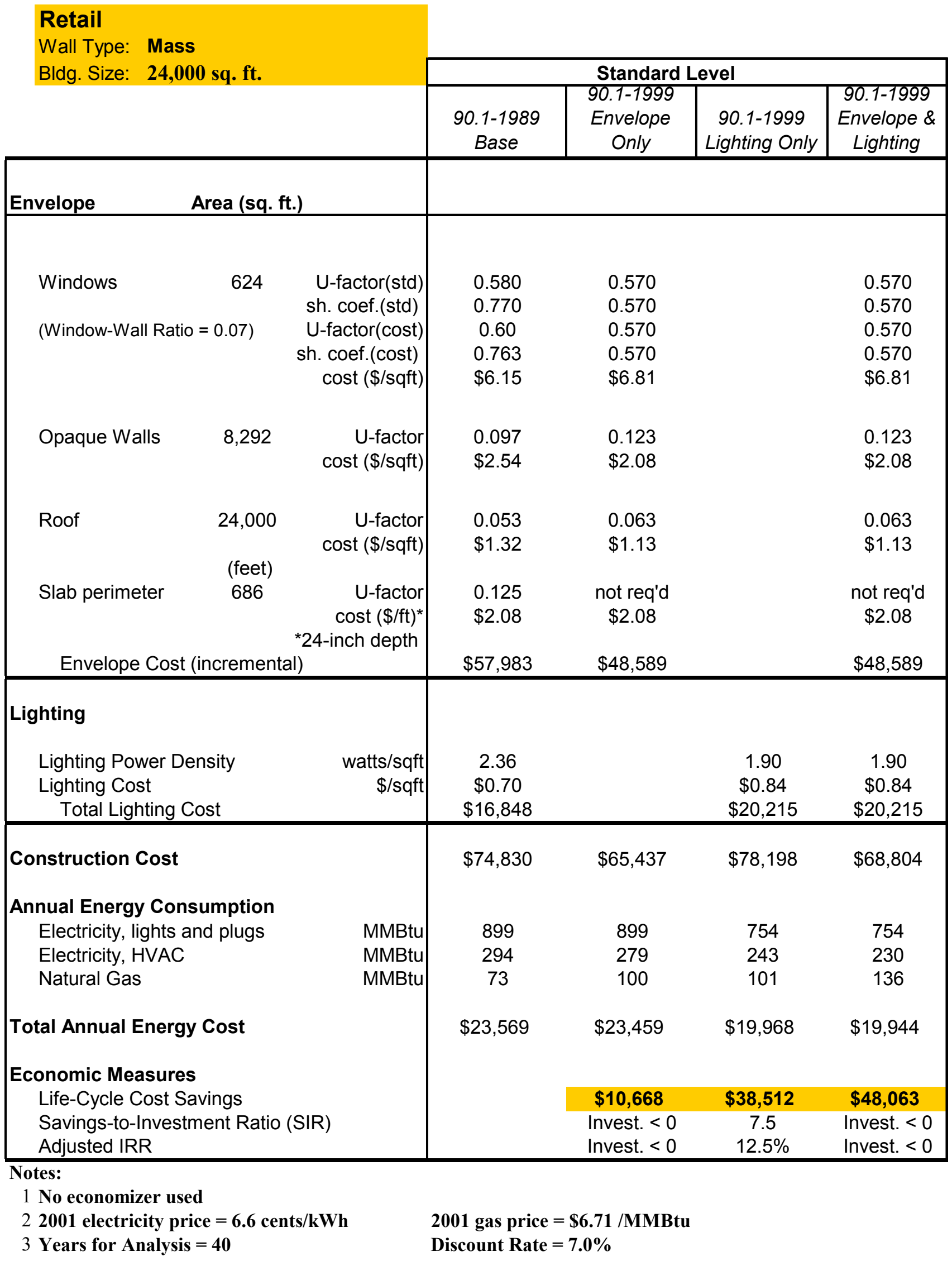

Life-cycle cost savings includes replacement costs and residual values 


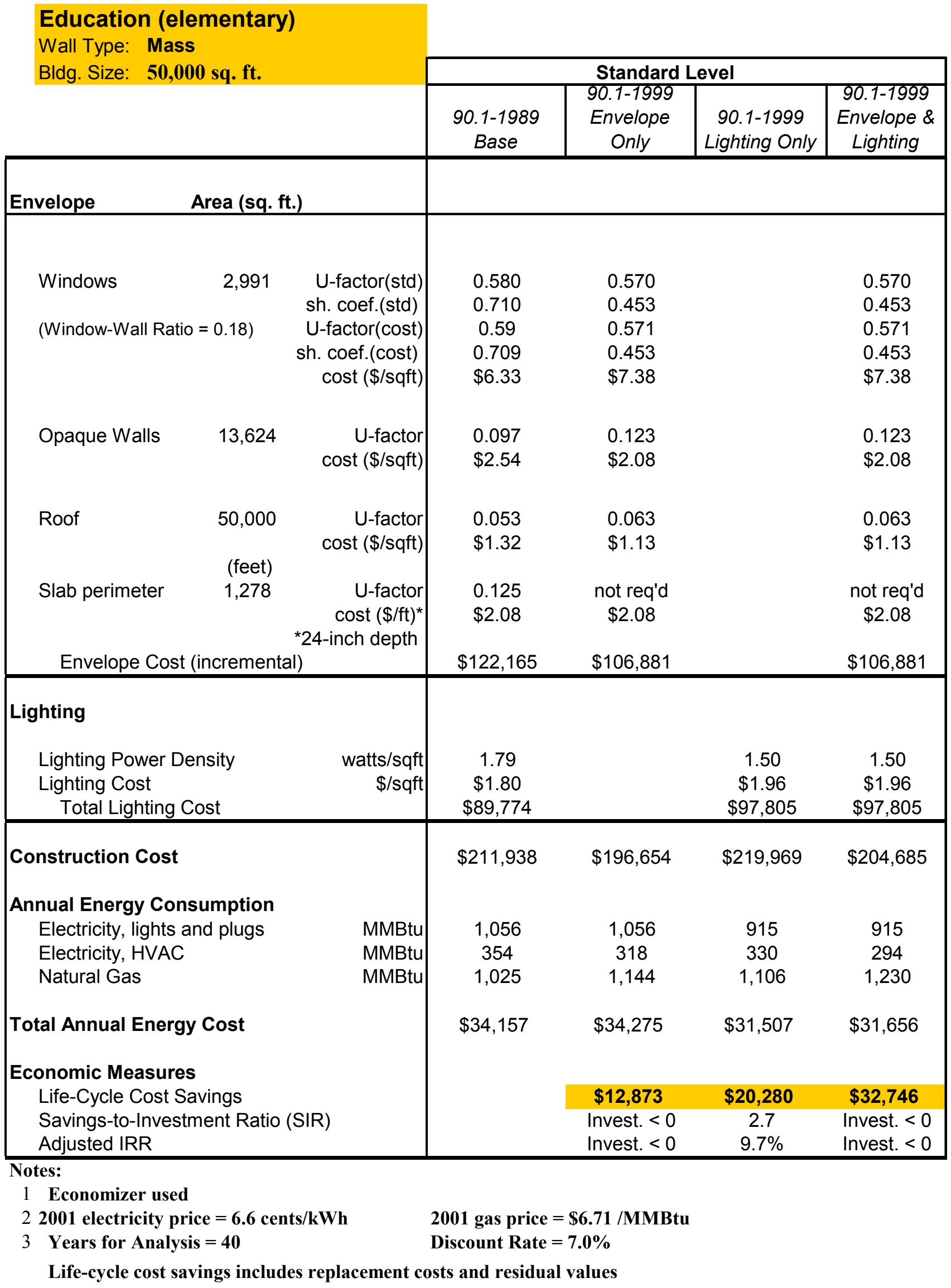




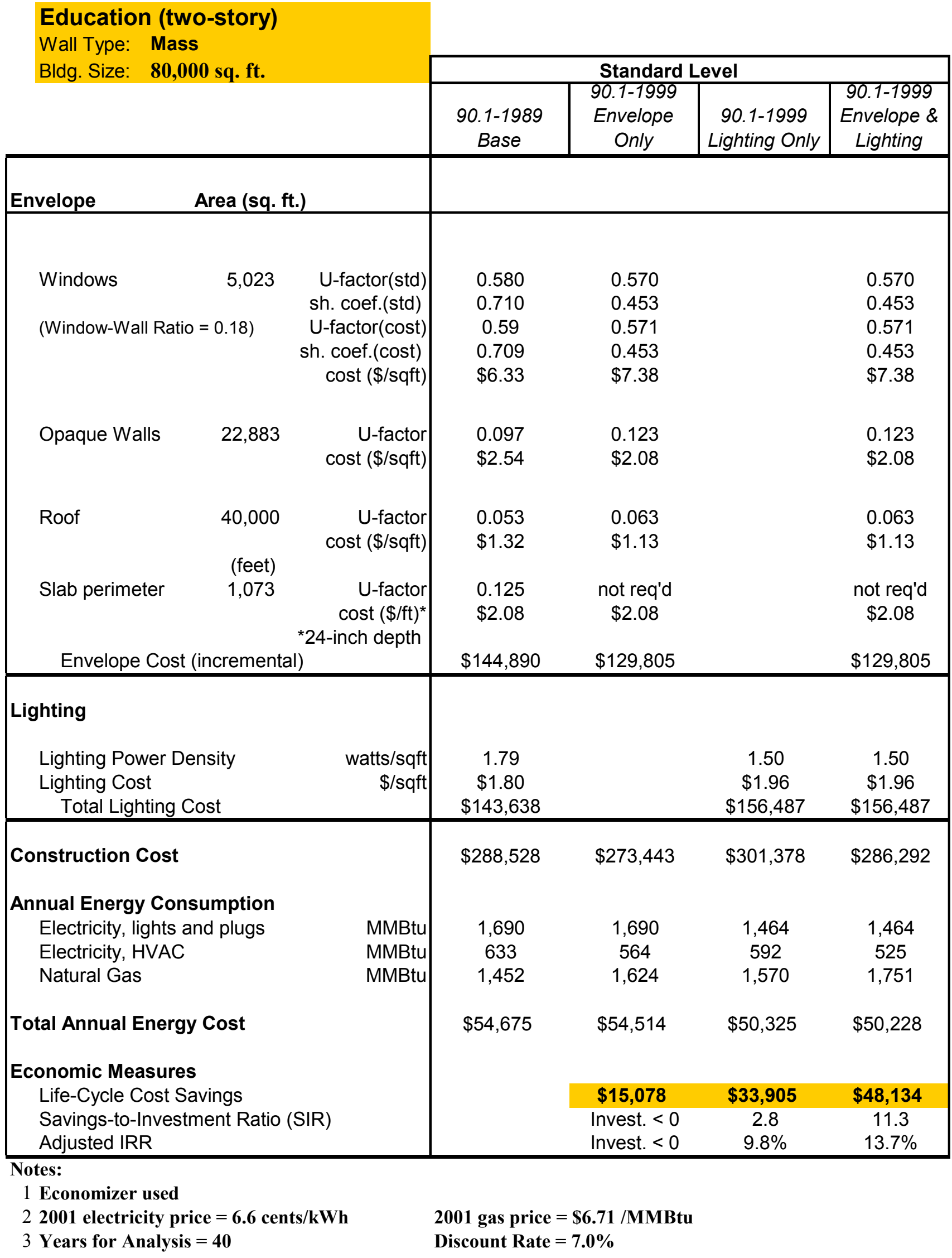

Life-cycle cost savings includes replacement costs and residual values 


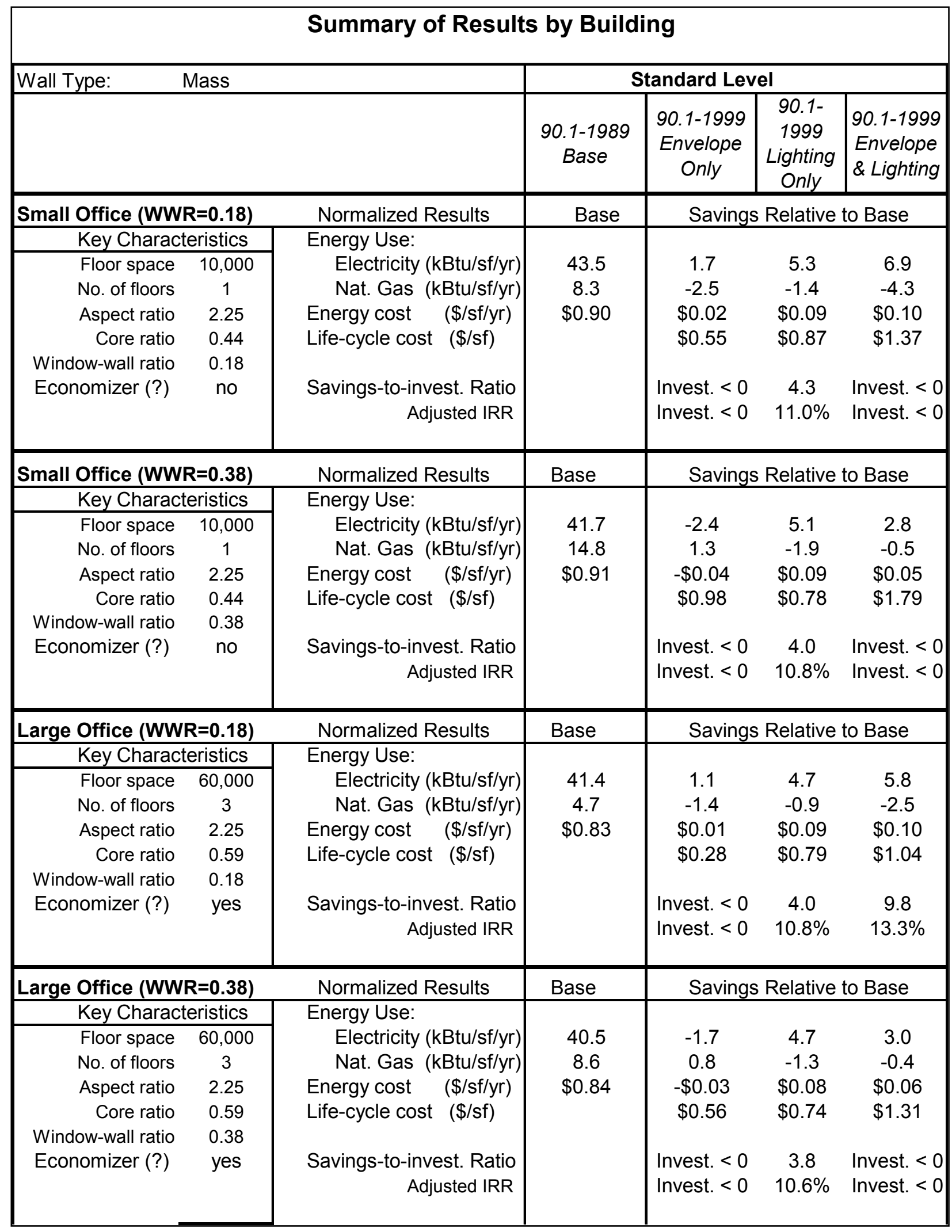




\section{Summary of Results by Building (continued)}

\begin{tabular}{|c|c|c|c|c|c|c|}
\hline Wall Type: & Mass & & & andard Lev & & \\
\hline & & & $\begin{array}{l}\text { 90.1-1989 } \\
\text { Base }\end{array}$ & $\begin{array}{c}\text { 90.1-1999 } \\
\text { Envelope } \\
\text { Only }\end{array}$ & $\begin{array}{c}\text { 90.1- } \\
1999 \\
\text { Lighting } \\
\text { Only }\end{array}$ & $\begin{array}{l}\text { 90.1-1999 } \\
\text { Envelope } \\
\text { \& Lighting }\end{array}$ \\
\hline Retail & & Normalized Results & Base & Savings & Relative & to Base \\
\hline Key Charac & ristics & Energy Use: & & & & \\
\hline Floor space & 24,000 & Electricity (kBtu/sf/yr) & 49.7 & 0.6 & 8.1 & 8.7 \\
\hline No. of floors & 1 & Nat. Gas (kBtu/sf/yr) & 3.1 & -1.1 & -1.1 & -2.6 \\
\hline Aspect ratio & 2.50 & Energy cost $\quad(\$ / s f / y r)$ & $\$ 0.98$ & $\$ 0.00$ & $\$ 0.15$ & $\$ 0.15$ \\
\hline Core ratio & 0.61 & Life-cycle cost $(\$ / s f)$ & & $\$ 0.44$ & $\$ 1.60$ & $\$ 2.00$ \\
\hline Window-wall ratio & 0.07 & & & & & \\
\hline Economizer (?) & no & $\begin{array}{r}\text { Savings-to-invest. Ratio } \\
\text { Adjusted IRR }\end{array}$ & & $\begin{array}{l}\text { Invest. }<0 \\
\text { Invest. }<0\end{array}$ & $\begin{array}{c}7.5 \\
12.5 \%\end{array}$ & $\begin{array}{l}\text { Invest. }<0 \\
\text { Invest. }<0\end{array}$ \\
\hline Education (eleme & tary) & Normalized Results & Base & Savings & Relative & to Base \\
\hline Key Charac & eristics & Energy Use: & & & & \\
\hline Floor space & 50,000 & Electricity (kBtu/sf/yr) & 28.2 & 0.7 & 3.3 & 4.0 \\
\hline No. of floors & 1 & Nat. Gas (kBtu/sf/yr) & 20.5 & -2.4 & -1.6 & -4.1 \\
\hline Aspect ratio & 6.00 & Energy cost $\quad(\$ / s f / y r)$ & $\$ 0.68$ & $\$ 0.00$ & $\$ 0.05$ & $\$ 0.05$ \\
\hline Core ratio & 0.63 & Life-cycle cost (\$/sf) & & $\$ 0.26$ & $\$ 0.41$ & $\$ 0.65$ \\
\hline Window-wall ratio & 0.18 & & & & & \\
\hline Economizer (?) & yes & Savings-to-invest. Ratio & & Invest. $<0$ & 2.7 & Invest. $<0$ \\
\hline & & Adjusted IRR & & Invest. $<0$ & $9.7 \%$ & Invest. $<0$ \\
\hline Education (two-s & ry) & Normalized Results & Base & Savings & Relative & to Base \\
\hline Key Charac & eristics & Energy Use: & & & & \\
\hline Floor space & 80,000 & Electricity (kBtu/sf/yr) & 29.0 & 0.9 & 3.3 & 4.2 \\
\hline No. of floors & 2 & Nat. Gas (kBtu/sf/yr) & 18.2 & -2.2 & -1.5 & -3.7 \\
\hline Aspect ratio & 5.00 & Energy cost $\quad(\$ / s f / y r)$ & $\$ 0.68$ & $\$ 0.00$ & $\$ 0.05$ & $\$ 0.06$ \\
\hline Core ratio & 0.62 & Life-cycle cost (\$/sf) & & $\$ 0.19$ & $\$ 0.42$ & $\$ 0.60$ \\
\hline Window-wall ratio & 0.18 & & & & & \\
\hline Economizer (?) & yes & Savings-to-invest. Ratio & & Invest. $<0$ & 2.8 & 11.3 \\
\hline & & Adjusted IRR & & Invest. $<0$ & $9.8 \%$ & $13.7 \%$ \\
\hline
\end{tabular}

